IZA DP No. 9753

More Unequal, But More Mobile?

Earnings Inequality and Mobility in OECD Countries

Andrea Garnero

Alexander Hijzen

Sébastien Martin

February 2016 


\title{
More Unequal, But More Mobile? Earnings Inequality and Mobility in OECD Countries
}

\author{
Andrea Garnero \\ OECD, Université Libre de Bruxelles and IZA \\ Alexander Hijzen \\ $O E C D$, IMF and IZA \\ Sébastien Martin \\ OECD

\section{Discussion Paper No. 9753 \\ February 2016} \\ IZA \\ P.O. Box 7240 \\ 53072 Bonn \\ Germany \\ Phone: +49-228-3894-0 \\ Fax: +49-228-3894-180 \\ E-mail: iza@iza.org
}

Any opinions expressed here are those of the author(s) and not those of IZA. Research published in this series may include views on policy, but the institute itself takes no institutional policy positions. The IZA research network is committed to the IZA Guiding Principles of Research Integrity.

The Institute for the Study of Labor (IZA) in Bonn is a local and virtual international research center and a place of communication between science, politics and business. IZA is an independent nonprofit organization supported by Deutsche Post Foundation. The center is associated with the University of Bonn and offers a stimulating research environment through its international network, workshops and conferences, data service, project support, research visits and doctoral program. IZA engages in (i) original and internationally competitive research in all fields of labor economics, (ii) development of policy concepts, and (iii) dissemination of research results and concepts to the interested public.

IZA Discussion Papers often represent preliminary work and are circulated to encourage discussion. Citation of such a paper should account for its provisional character. A revised version may be available directly from the author. 


\section{ABSTRACT \\ More Unequal, But More Mobile? Earnings Inequality and Mobility in OECD Countries*}

This paper provides comprehensive cross-country evidence on the relationship between earnings inequality and intra-generational mobility by simulating individual earnings and employment trajectories in the long-term using short panel data for 24 OECD countries. On average across countries, about $25 \%$ of earnings inequality in a given year evens out over the life cycle as a result of mobility. Moreover, mobility is not systematically higher in countries with more earnings inequality in general. However, a positive and statistically significant relationship is found only in the bottom of the distribution. This reflects the role of mobility between employment and unemployment and not that of mobility up and down the earnings ladder.

JEL Classification: $\quad$ E24, J30, J62, O57

Keywords: intra-generational mobility, life-time inequality, earnings-experience profiles, simulation

Corresponding author:

Alexander Hijzen

OECD

2 , rue André-Pascal

75775 Paris Cedex 16

France

E-mail: alexander.hijzen@oecd.org

\footnotetext{
* This paper builds on the work done for Chapter 4 of the OECD Employment Outlook 2015. It has been produced with the financial and substantive assistance of the European Union, as part of the OECD project "Defining, Measuring and Assessing Job quality and its Links to Labour Market Performance and Well Being" [VS/2013/0108 (SI2.666737)]. The views expressed in this paper are those of the authors and cannot be attributed to the European Union, the OECD or its member countries. The authors would like to thank Audra Bowlus and Jean-Marc Robin for kindly sharing their codes to allow building on their work (Bowlus and Robin, 2012) and ensure a certain degree of consistency between the present analysis and their original work. While the codes have been adjusted and extended in numerous directions the basic framework has remained the same. The authors are also grateful to Andrea Bassanini, Stijn Broecke, Hervé Boulhol, Audra Bowlus, Orsetta Causa, Sandrine Cazes, Jim Davies, Paolo Falco, Gary Fields, Eric Gould, Mark Keese, Herwig Immervoll, Hartmut Lehmann, Ana Llena-Nozal, Balint Menyhert, Fabrice Murtin, Stephen Jenkins, Michele Pellizzari, Thomas Piketty, Jean-Marc Robin, Alfonso Rosolia, Stefano Scarpetta, Timothy Smeeding, Paul Swaim and Céline Thévenot as well as to the participants of the April 2015 meeting of the Working Party on Employment, the $10^{\text {th }}$ IZA/World Bank Conference on Employment and Development and research seminars at the OECD, the IMF and the Paris School of Economics for useful discussions, comments and suggestions. The authors are responsible for any remaining errors.
} 


\section{Introduction}

In many countries the perception that inequality has deepened and upward mobility has stalled has become a prominent issue in the political debate. A particular contentious issue is whether there is any connection between earnings inequality and earnings mobility across the working life or even across generations. If inequality and mobility are closely related, crosscountry comparisons of inequality within a given year give a poor indication of the true depth of economic inequalities because mobility has a tendency to even out earnings differences in the long-term. Given the importance of mobility in determining the nature and depth of economic inequalities, perceptions of mobility play an important role in shaping attitudes to inequality and redistribution. Indeed, De Tocqueville (1835) first proposed the idea that the difference in attitudes towards redistribution between Europe and the United States can be explained by differences in mobility rates. More recently, Piketty (1995) and Benabou and Ok (2001) have shown how perceived mobility can affect preferences for redistribution across countries. ${ }^{1}$ Surprisingly, little is known about the actual degree of earnings mobility in different countries.

This paper contributes to the debate by focusing on the relationship between earnings inequality and intra-generational mobility. ${ }^{2}$ Despite its importance, there is no comprehensive cross-country evidence, with previous studies typically focusing on comparisons between the United States and one or a few European countries (never more than five). Burkhauser and Poupore (1997), OECD (1997), Aaberge et al. (2002), Aaberge and Mogstad (2012) find that

\footnotetext{
Apart from affecting social welfare through its impact on inequality, mobility also affects welfare though its impact on risk. This is especially important when mobility takes the form of large unanticipated earnings changes and the ability to insure against earnings volatility is limited. While important, this aspect of mobility is not considered in this paper.

Krueger (2012) shows that the relationship between income inequality and inter-generational mobility, described by the so-called "Great Gatsby curve" (a reference to the character who rises "from the rags to riches" in F. Scott Fitzgerald's novel), is negative: countries with higher levels of income inequality exhibit lower levels of inter-generational mobility.
} 
mobility in the United States is either lower or similar in Continental European countries. By contrast, Flinn (2002), Bayaz-Ozturk et al. (2012) and Bowlus and Robin (2012) suggest that mobility is more equalising in the United States. ${ }^{3}$ In sum, the expectation that mobility is substantially higher in high inequality countries such as the United States has only received mixed support. ${ }^{4}$ Moreover, the small number of countries considered in previous studies makes it hard to draw strong conclusions about the relationship between inequality and intra-generational mobility.

The lack of more comprehensive evidence on the relationship between inequality and intragenerational mobility largely reflects data limitations. Measuring mobility requires comparable data that allow individuals to be followed over a substantial part of their working lives. In principle, this can be done by mobilising data that are collected for administrative purposes such as social security records or by making use of cohort surveys that are specifically designed to follow individuals over long periods of time. Unfortunately, such data are only available for a limited number of countries and tend to be difficult to compare internationally. While in most OECD countries high-quality household or labour force panel datasets exist, these typically do not allow individuals to be followed for more than a few years. This is because they either have a rotating panel design or suffer from substantial attrition as it tends to be difficult to keep subjects in panel surveys for extended periods of time.

3 Studies using administrative records to analyse intra-generational mobility within countries include Aaberge and Mogstad (2012) for Norway, Björklund (1993) for Sweden, Bönke et al. (2015) for Germany, Kopczuk et al. (2010) and Guvenen et al. (2015) for the United States and Waaijers and Lever (2013) for the Netherlands. These studies typically suggest that the bulk of earnings differences at a point in time is permanent, but that earnings mobility also plays a significant role in smoothing out temporary fluctuations in earnings.

$4 \quad$ These mixed findings reflect the sensitivity of the results with regards to: i) numerous comparability issues across datasets and samples; ii) the choice between labour earnings or household incomes; iii) differences in the concepts of mobility and inequality; and iv) the extent to which they isolate positional mobility in a stable distribution of earnings from structural mobility (i.e. movements in the entire distribution), due to structural changes or changes in macro-economic conditions. 
The main contribution of this paper is to provide for the first time comprehensive evidence across a large number of advanced economies on the relationship between inequality and intragenerational mobility. In order to overcome the data limitations that have prevented previous studies from doing so, this paper makes use of simulation techniques to generate individual earnings and employment trajectories in the longer term using short panel data for 24 OECD countries. The simulation methodology builds on previous work by Buchinsky and Hunt (1999) and Bowlus and Robin (2004, 2012). Buchinsky and Hunt (1999) employ flexible statistical methods based on the estimation of transition matrices to analyse how mobility has changed during the 1980s in the United States. Building on this work, Bowlus and Robin $(2004,2012)$ propose a simulation model of individual employment and earnings trajectories. Bowlus and Robin (2004) use the simulation approach to document how life-time inequality has evolved in the United States, while Bowlus and Robin (2012) compare the equalising effect of mobility over the life course across five advanced economies. The present paper adapts the simulation approach used in Bowlus and Robin (2012) while refining the model of earnings dynamics and unemployment benefit recipiency.

Considerable effort is made to ensure that the simulation approach captures the actual degree of earnings mobility well. This is primarily done by using an unique database for Italy drawn from social-security records that allows following individuals for over 25 years. The validation exercise shows that the statistical model of long-term earnings captures the actual evolution of earnings, including the degree of earnings mobility, very well. As both the value of adding an additional year and the fit of the model decline as the time horizon is extended, the paper focuses on longterm earnings (defined over ten or twenty years), rather than earnings over entire working careers as was the case in Bowlus and Robin (2004, 2012). 
Since inequality and mobility can be defined in many ways (see Jäntti and Jenkins, 2015, for a comprehensive survey of the literature on intra-generational and inter-generational mobility), it is important to be clear at the outset what is meant with those terms in the present paper. Inequality refers here, unless specified otherwise, to the distribution of monthly earnings across all active individual in the labour force, including both the employed and the unemployed, after taking account of all unemployment benefits recipiency. ${ }^{5}$ Earnings mobility refers to movements up and down the earnings ladder and movements in and out of employment, more formally, to changes in the earnings position of individuals in an otherwise stable distribution ("positional mobility"). It is measured in terms of the percentage reduction in short-term earnings inequality as a result of mobility (Shorrocks, 1978). The concept of mobility used in this paper has a number of important implications. First, we abstract from macro-economic dynamics that affect the level and distribution of earnings (e.g. economic growth, business cycle effects). Second, mobility is defined in terms of relative earnings changes and hence non-directional. An improvement in the relative earnings position of one person is necessarily associated with a deterioration in that of at least one other person. Third, mobility is zero when the earnings position of individuals remains unchanged from one year to the next and one when the position of all persons is exactly reversed.

The analysis in this paper provides three main insights. First, the results show that on average across the countries analysed, mobility, i.e. movements up and down the wage ladder and in and out employment, reduces inequality, as measured by the Gini index, by about $25 \%$ over the first 20 years of careers. This implies that approximately $75 \%$ of inequality within a year is permanent. Second, the cross-country correlation between mobility and inequality at a point in time tends to

This means that the concept of inequality is quite different from that used in the literature on wage inequality which has tended to focus on hourly wages of the employed. While this is reasonable in the context of studies that focus on inequality in a given year we believe a broader concept of inequality is more appropriate when focusing on inequality in the long-term. 
be weak and depends on the measure of inequality used. This means that the belief that higher inequality is compensated by higher mobility is not validated in general. Only when using inequality indices that focus on the tails of the distribution (e.g. P90/P10, P80/P20 ratios) is the relationship between inequality and mobility positive and statistically significant, while no statistically significant relationship exists using indices that make use of the entire distribution (e.g. Gini, Theil). Third, looking at the relationship between mobility and inequality along the entire earnings distribution, we find that the positive relationship between inequality and mobility that is observed when using the $\mathrm{P} 90 / \mathrm{P} 10$ or the $\mathrm{P} 80 / \mathrm{P} 20$ percentile ratios is driven by the relationship between inequality in the bottom of the distribution and movements between unemployment and employment. These results are robust to a series of sensitivity tests.

This remainder of the paper is structured as follows. Section 2 presents the simulation methodology in detail. Section 3 conducts a validation exercise of the simulation method using social security data for Italy. Section 4 describes the data for the cross-country analysis. Section 5 discusses the estimates of short-term inequality, long-term inequality and mobility across countries and socio-economic groups. Section 6 analyses the relationship between inequality and mobility across countries. Section 7 concludes.

\section{A simulation methodology for calculating the distribution of long-term earnings}

The simulation methodology used in this paper draws heavily on previous work by Bowlus and Robin (2012), while refining it further in a number of important ways. First, as explained in more detail below, the present approach allows for somewhat more elaborate earnings dynamics. It is shown using social-security data for Italy that this substantially improves the ability of the simulation model to capture the actual degree of mobility in the data over long periods. Second, 
we allow for a more detailed characterisation of unemployment insurance. While Bowlus and Robin (2012) assume that all the unemployed receive unemployment insurance according to a uniform replacement rate for each country, the present analysis focuses on effective insurance which takes account of the coverage rate of unemployment insurance and the generosity of unemployment benefits (insurance and assistance). Moreover, both the probability of being covered and the replacement rate vary across individuals based on their observed characteristics.

The remainder of this section is structured as follows. It starts by discussing why and how structural mobility is removed from the data to isolate positional mobility within a stable distribution of earnings. It then sets out how the different parameters for the simulations are estimated. It concludes by describing how individual earning and employment trajectories are simulated based on the estimated parameters.

\subsection{Removing structural mobility}

When comparing mobility across countries it is important to isolate positional from structural mobility (MaCurdy, 2007). Structural mobility relates to changes in the distribution itself over time due to macro-economic developments, policy reforms or structural change. Positional mobility refers to changes in the position of individuals within an otherwise stable distribution of earnings. Since the present interest is in understanding the equalising effect of positional mobility on inequality in the long-term we seek to abstract from structural mobility. ${ }^{6}$ In much of the previous literature structural mobility has been controlled for through the use of time dummies (MaCurdy, 2007). We go slightly further and follow Bowlus and Robin (2012) by removing any structural variation of earnings by regressing log earnings on time dummies interacted with

6 Taking account of structural mobility would require a fully-fledged structural model of macro-economic dynamics over the life-course which is well beyond the scope of this paper. 
education dummies with 2010 as the reference year. ${ }^{7}$ In addition to controlling for changes in macro-economic conditions (e.g. growth, business cycle) this also controls for changes in the educational structure of earnings. Bowlus and Robin (2012) argue that this is likely to be sufficient in the present case given the short nature of the data. All remaining dynamics in earnings are interpreted as positional mobility. ${ }^{8}$

\subsection{Estimating the simulation parameters}

The simulation of individual earnings and employment dynamics requires estimating parameters to characterise earnings-experience profiles, earnings mobility within groups, employment mobility and the probability of being covered by unemployment benefits when unemployed.

Using adjusted earnings from the previous stage, $\widetilde{w}_{i t}$, fully flexible earnings-experience profiles by sex and education are estimated using the following Mincerian model:

(2.1) $\widetilde{w}_{i t}=z_{i t} \gamma+f_{i}+\epsilon_{i t}$

where $z_{i t}$ is a vector that includes the constant, a gender dummy, a set of education dummies, a cubic in potential experience and the full set of interaction terms composed of the cubic in potential experience, the education dummies and the gender dummy. The resulting earningsexperience profiles by sex and education are completely unrestricted. ${ }^{9}$ They effectively allow

7 The year 2010 is also used as the base year for the simulations. This means that the data used for the simulations are unaffected by this adjustment.

$8 \quad$ Where appropriate, the analysis abstracts from temporary changes in unemployment benefit systems in response to the crisis (e.g. the extension of the maximum duration of unemployment benefits in the United States).

9 The data do not allow controlling for additional variables that have been shown to be important for explaining earnings-experience profiles such as tenure and foreign-born status. 
characterising the degree of positional mobility between experience, education and gender groups. ${ }^{10} \mathrm{~A}$ individual-specific fixed effect, $f_{i}$, is allowed for in the fixed-effects specification (FE) but not in the specification based on ordinary least squares (OLS). The estimations explicitly allow for conditional heteroskedasticity using the feasible GLS procedure. This is implemented by regressing the squared residuals of equation (2) on $z_{i t}$ with parameter vector $\omega$ and re-estimating equation (2.1) with weights proportional to $1 / \sqrt{z_{i t} \widehat{\omega}}$.

The next step is to model earnings mobility within groups, i.e. movements in the distribution of earnings relative to the predicted earnings trajectories, as well as employment mobility, i.e. movements between employment and unemployment. To model earnings mobility within groups, we use the normalised residuals from the previous stage $\hat{u}_{i t}=\hat{\epsilon}_{i t} / \sqrt{z_{i t} \widehat{\omega}}$, which capture the variation in earnings within groups, and use these to allocate all employed individuals to residual earnings deciles. In a somewhat ad hoc way, unemployment is treated as an additional state, giving eleven possible origin and destination states. In order to characterise the transition matrix using relatively small samples, we parametrically estimate the transition probabilities using multinomial logit models. To avoid having excessively small destination cell sizes that prevent the model from converging, far away cells are regrouped by restricting the maximum distances between wage deciles, as in Bowlus and Robin (2012). The maximum distance is restricted to three in the baseline results whereas results based on maximum distances of four and two are reported in the sensitivity analysis. ${ }^{11}$ We estimate the following multinominal logit model for each origin state, $m$ :

10 Since this component of mobility does not entail any uncertainty, it does not contribute to risk but reduces long-term inequalities when expected earnings-experience profiles differ across socio-economic groups.

For example, using a maximum distance of 3 , all destinations of persons in the first decile who transition to the fourth decile or higher are treated as the same state. 


$$
P\left(m, n \mid h_{i t}\right)=\frac{\exp \left[h_{i t} \theta(m, n)\right]}{\sum_{m=0}^{M=10} \exp \left[h_{i t} \theta(m, n)\right]}
$$

where $P(m, n)$ is the probability of moving from state $q_{i t}=m$ at time $\mathrm{t}$ to state $q_{i t+1}=n$ at time $t+1$ with $\sum_{j} P\left(m, n \mid h_{i t}\right)=1$ and $h_{i t}$ is a vector including a constant, a gender dummy, education dummies, a cubic in potential experience. In our preferred specification (referred to as DYN), we also include a set of dummies for the previous state $q_{i t-1}=l$ at time $t-1$. This dynamic specification is only used when estimating (2.1) with OLS and not when allowing for a person fixed effect in the first stage (FE). The reason for this is that the person fixed effects are estimated over just three years but are kept constant for the simulation of earnings and employment trajectories in the long-term. This means that the simulations based on the fixed-effects specification are likely to already imply too much persistence in earnings dynamics and, hence, to underestimate the degree of mobility. However, as will become clear when discussing the results from the validation exercise, OLS has a tendency to overstate the actual degree of mobility in the data. ${ }^{12}$ To avoid estimating transition paths associated with very few individuals, the lagged states are regrouped in the same way as the destination states.

As explained below, the expected wage growth and transition parameters obtained from estimating equations (2.1) and (2.2) are sufficient to simulate the earnings trajectories of those employed. To also take account of replacement earnings when unemployed in the form of unemployment benefits one has to determine whether or not they receive unemployment benefits and if so how much. The probability of being covered by unemployment benefits is modelled using the following logistic regression:

$12 \quad$ Bowlus and Robin (2012) use OLS and FE to obtain respectively upper and lower bound estimates of mobility. 


$$
P\left(c=1 \mid r_{i t}\right)=\frac{1}{1+\exp \left(-r_{i t} \vartheta\right)}
$$

where $P\left(c=1 \mid r_{i t}\right)$ refers to the probability of receiving unemployment benefits $(c=1)$, conditional on a vector $r$ that includes a constant, education dummies, a quadratic of potential experience, a dummy for having previous work experience, and two unemployment-duration dummies (12-24 months and 24+ months) and a set of interaction terms between gender with the other variables in the model. ${ }^{13}$

The parameters for the unemployment replacement rate come directly from the OECD Taxesand-Benefits model. For the present purposes, the replacement rate is allowed to vary by decile of the previous wage and takes account of non-linearities in the replacement rate with respect to the previous wage. This is important because in most OECD countries unemployment benefits are capped at a given ceiling. Moreover, to capture the fact that in many OECD countries replacement rates decline with the duration of unemployment, replacement rates are calculated separately for the first year of unemployment, the second year and the third year onward.

\subsection{Simulating individual earnings and employment trajectories}

The estimated parameters are used to simulate the employment and earnings trajectories for individuals present in the reference year (2010). Rather than simulating the remaining working lives of each individual until retirement as do Bowlus and Robin (2012), the present analysis simulates the employment and earnings histories for all active individuals in the reference year aged 15 to 54 for a period of ten years (or, in another setting, active individuals aged 15 to 34 for a period of twenty years). This means that we simulate on average shorter working trajectories

13 The probability of being covered not only captures eligibility to unemployment benefits among the unemployed, but also the extent to which eligible unemployed persons claim the benefits to which they are entitled. 
than Bowlus and Robin (2012). Since the information content of the simulations is likely to decline for further away years, this choice was made to remain as close to the actual data as possible. Simulating equal length trajectories of ten years for all individuals rather than estimating the remaining working lives until retirement for individuals of different ages also avoids having to make assumptions on discount factors for calculating present values. ${ }^{14}$

To simulate the ten year employment and earnings trajectories for all individuals in the reference year we proceed as follows. First, based on equation (2.1), we calculate the predicted expected wage for each individual based on its gender, education and potential experience and for each year, $z_{i t} \hat{\gamma}$. Second, when using the FE-based model, we also retrieve the individual's fixed effect, $\hat{f}_{i}$. Third, based on a sequence of random draws for each year and the individual-specific predicted transition probabilities from (2.2), we assign individuals to an employment state and, if employed, an earnings decile in each year.

For those employed, we need to determine the precise rank of each individual within deciles. Previous studies typically assume that the rank within deciles is preserved, even if individuals change deciles, or that rank is assigned randomly within deciles. We follow Bowlus and Robin (2012) who propose a nearest-neighbour procedure which entails predicting the rank at $t+1$ that yields the closest match to its original rank in the overall earnings distribution and is also consistent with the predicted decile at $t+1$. This means that individuals that move to higher deciles will be placed in the bottom of these deciles, individuals who move down will be placed in the top of these deciles and individuals who stay in the same decile will retain a similar rank as in the original distribution at $t$. Having determined the rank distribution, it is straightforward to obtain the empirical cumulative density function. Assuming that residual wages are log-normally

14 Bönke et al. (2015) show that this can have large implications for the measured degree of mobility. 
distributed, one can generate the standard normal distribution of residual log wages by inverting the cumulative density function. Multiplying the normalised wages by $\sqrt{z_{i t} \widehat{\omega}}$ yields the residual log wage for each employed individual.

For those who are employed, we can now calculate their wage in each year $t$ to $t+s$ as follows:

$$
\text { (2.4a) } \widehat{w}_{i t}^{E}=\exp \left(z_{i t} \hat{\gamma}+\hat{f}_{i}+\hat{u}_{i t} \sqrt{z_{i t} \widehat{\omega}}\right)
$$

where $z_{i t} \hat{\gamma}$ refers to the predicted expected log wage for each individual based on its gender, education and potential experience at time $t, \hat{f}_{i}$ the individual-specific fixed effects (only used in the FE-based model) and $\hat{u}_{i t} \sqrt{z_{i t} \widehat{\omega}}$ the residual log wage based on the random allocation of individuals across potential destination deciles conditional on their origin state, gender, experience and potential experience.

For those unemployed in the reference year or at any point during the simulation period, we need to calculate replacement earnings. First, we determine whether an unemployed person is covered by unemployment benefits. This is done by randomly assigning coverage to unemployed persons conditional on their predicted probability of being covered (2.3) based on their gender, education, potential experience and time spent in unemployment. Second, given coverage status, we impute replacement earnings. Those who do not receive unemployment benefits are given zero replacement earnings. For those who receive unemployment benefits, we need the last wage before becoming unemployed which is calculated as $z_{i t-u} \hat{\gamma}$ in the reference year or $\widehat{w}_{i t-u}$ during the years of the simulation period. We then use the applicable replacement rate given the last wage and the time spent in unemployment, as obtained from the OECD Taxes-and-Benefits model. Replacement earnings of the unemployed are thus calculated as follows: 
(2.4b) $\widehat{w}_{i t}^{U}=\rho_{i} \widehat{w}_{i t-u}$ if $c_{i}=1$ or $\widehat{w}_{i t}^{U}=0$ if $c_{i}=0$

Equations (2.4a) and (2.4b) jointly allow simulating the employment and earnings trajectories for all active persons aged 15 to 55 in the actual data in the reference year. ${ }^{15}$

Having defined individual earnings trajectories, it is now possible to compute measures of inequality in the short and the longer-term. ${ }^{16}$ Short-term inequality is defined as inequality within a given year averaged over time. Long-term inequality is defined as inequality of average earnings. The percentage reduction in short-term inequality that is obtained by averaging earnings over time is referred to as mobility (Shorrocks, 1978). Formally, it is defined as one minus the ratio of longterm to short-term inequality:

(2.5) $M=1-\frac{I\left(\frac{1}{T} \sum_{t}^{T} w_{t}\right)}{\left(\sum_{t}^{T} \eta_{t} I\left(w_{t}\right)\right)}$

where $I($.$) represents the inequality metric (Gini, Theil, MLD, P90/P10 or P80/P20 in this$ paper), $w_{t}$ represents the vector of individual earnings in year $t$, and $\eta_{t}$ indicates the share of total earnings in year $t$ in the sum of total earnings over the $T$ year period (10 or 20 in this paper). $M$

15 The present value of earnings $v$ in year $t$ in the reference year for person $i$ is given by: $v_{i t}=\frac{\widehat{w}_{i t}^{E}+\widehat{w}_{i t}^{U}}{(1+\delta)^{t}}$ where $\delta$ refers to time preferences in the form of a discount factor. A larger discount factor tends to increase the present value of earnings of persons with steep earnings-experience profiles compared with individuals with more shallow or even declining earnings-experience profiles. As a result, the choice of the discount factor can have important implications for comparisons of mobility across different age groups. To avoid influencing interpersonal comparisons in this way the baseline results do not discount the future.

As in Bowlus and Robin (2012), measurement error is not modelled. Previous studies have found that measurement error in wage and earnings data is non-classical and mean reverting (Gottschalk and Huynh, 2010). Non-classical measurement error leads to a reduction in measured inequality, while classical measurement error increases it. The effect of measurement error on mobility is less clear. In order to examine the role of measurement error in household surveys such as those used in the present paper, Gottschalk and Huynh (2010) match the US Survey of Income and Program Participation with US tax records (which may be considered free of measurement error) for the same individuals. They find that the effects of non-classical measurement error are largely offset when estimating mobility, as measured by the inter-temporal correlation in earnings. To the extent that their results carry over in the present context the bias as a result of measurement error may be minor. 
ranges from 0 (no equalising mobility) to 1 (fully equalising mobility) as long as the inequality measure used satisfies the transfer principle (i.e. inequality falls if a transfer from a richer to a poorer person is made and vice versa). Since this is not the case for percentile ratios (e.g. a transfer from P70 to P30 does not affect the P90/P10 ratio), these are arguably less appropriate for measuring the overall degree of mobility. However, as will become clear in the results section, their "local" nature is helpful for assessing how the relationship between inequality and mobility varies along the distribution of earnings.

\section{Validation of the simulation methodology using Italian Social Security data}

\subsection{Data}

The simulation procedure is validated using longitudinal data from Italy's National Social Security Institute (Istituto Nazionale della Previdenza Sociale - INPS). The data represent a random sample of individuals working in the private sector during the period 1985 to 2012. This corresponds to around $6 \%$ of the workforce or 1.1 million persons on average per year. ${ }^{17}$

The data record all job spells in a year for each individual in the sample, including their start and stop dates, total gross earnings (before taxes and transfers and including bonuses, performance pay, overtime payments), age, gender, contract type, industry, region, working time, number of days and weeks worked. In the case of multiple job spells per individual per year, wages are summed across all job spells in that year. The analysis focuses on gross annual earnings. While the earnings data are of very high quality, the data were trimmed by removing individuals in the bottom and top percentiles of the earnings distribution in each gender and potential experience group (0-10 years, 10-20 years, 20-30 years, 30-40 years, 40 years or more) in a given

17 Individuals are selected on the basis of their date of birth (all persons born the $1^{\text {st }}$ or $9^{\text {th }}$ of each month). 
year. Since information on educational attainment is not available, skills are measured on the basis of occupations in terms of blue and white collar jobs. The measure of skills is kept constant over time using the highest level recorded during the period 2002 to 2012.

For the purposes of the validation exercise, the analysis focuses on individuals who are continuously employed during the period 2002 to 2012. It does not take account of employment mobility, i.e. movements between employment and unemployment, since the data only provide information on employed workers in the private sector. ${ }^{18}$ To allow for consistent comparisons between the actual and simulated data, the former are adjusted for changes in the level and skill structure of earnings since 2002, in the same way as in the simulated data.

\subsection{Rank correlations}

To validate the simulation methodology we compare the degree of earning mobility in the actual and the simulated data. The most direct way of doing this is by means of Spearman's rank correlations between individual earnings across different years. In order to assess the ability of the simulations to replicate the pattern of earnings mobility along different segments of the distribution of earnings, Table 1 documents the actual and predicted rank correlations between individual earnings in 2003 and 2004 conditional on their position in the distribution of earnings in 2003.

The rank correlations in the actual data suggest that positional mobility is concentrated in the bottom half of the distribution of initial earnings and declines with initial earnings for earnings above the median. The rank correlation is very low in the first decile (i.e. showing high mobility),

$18 \quad$ Workers who are not employed in the private sector may be employed in the public sector, be unemployed or inactive. 
then is stable in deciles from 2 to 6 before gradually rising to 85 in the highest decile. The significance of differences in positional mobility across the earnings distribution is an important reason for adopting the flexible method used here instead of parametric approaches that impose uniform wage dynamics.

The extent to which the simulated data capture the varying importance of earnings dynamics across the distribution of initial earnings differs across specifications. All three specifications have a tendency to underestimate the degree of positional mobility in the bottom of the distribution and overestimate it in the centre and top of the distribution. However, the OLS and DYN specifications perform much better than that based on FE. The average absolute difference between the predicted and actual rank correlation across deciles is about 50\% higher in the FE specification (38\% instead of $28 / 29 \%$ ). Moreover, while the pattern of mobility based on the FE specification is broadly symmetric with about the same amount of positional mobility in the bottom and top of the initial distribution of earnings, the OLS and DYN specifications suggest considerably more positional mobility in the bottom of the distribution of initial earnings than in the top, consistent with the pattern in the actual rank correlations.

\section{[Insert Table 1 here]}

In order to assess the ability of the simulations to capture long-term earnings dynamics in addition to those in the short-term, Table 2 shows rank correlations between individual earnings in the first year of the simulations and those, respectively, three, six and nine years later. As before, the rank correlations are shown by decile of the initial distribution of earnings. Extending the observation period reduces actual rank correlations and increases mobility. The average rank correlation across deciles declines from 0.42 for one-year differences (Table 1) to 0.29 for three- 
year differences, to 0.20 for six-year differences and 0.16 for nine-year differences. The qualitative pattern of the rank correlations across deciles remains similar when increasing the time differences, with mobility being concentrated in the bottom the distribution and declining rapidly when approaching the top of the distribution. The performance of the simulations across specifications also remains broadly similar, with OLS and DYN doing significantly better than the FE specification. DYN performs best across durations with the average normalised deviation increasing to 0.38 over three years, 0.47 over six years and 0.52 over nine years as compared with 0.39 for OLS after three years, 0.48 after six years and 0.53 after nine years and 0.54 for FE after three years, 0.74 after six years and 0.82 after nine years. The decline in precision over time provides an argument for restricting the simulation period to ten years.

\section{[Insert Table 2 here]}

\subsection{The equalising effect of mobility}

The final step of the validation exercise involves comparing the degree of earnings mobility in the simulated data over the period 2003 to 2012 with the degree of mobility observed in the actual data during the same period as measured by the Shorrock's index which is the main mobility measure used in this paper. Figure 1 shows the Shorrocks mobility index which measures the percentage reduction in earnings inequality, in terms of the Gini index, when individual earnings are averaged over time Panel A shows that mobility reduces earnings inequality by $7 \%$ over the ten years from 2003 to 2012 in the actual data. Panel B shows that the effects of earnings mobility over ten years vary considerably across birth cohorts, with mobility reducing withincohort inequality by almost $30 \%$ among young cohorts born after 1980 but by only around 5\% for 
older cohorts born before $1960 .{ }^{19}$ In both cases, the simulated data based on the OLS model overestimate mobility, while the model based on fixed-effects underestimates mobility. By contrast, the model where transitions are estimated using a dynamic multinomial logit matches the actual degree of mobility rather well. This is the case over time as well as across cohorts.

\section{[Insert Figure 1 here]}

Overall the comparison of earnings mobility in the simulated and the actual data shows that the simulation methodology is able to predict the main features of positional mobility over up to ten years reasonably well. Since the dynamic specification performs best overall this will be the focus of the results section.

\section{Data}

\subsection{Panel data on individual earnings and employment status}

For the purposes of the simulations of employment and earnings trajectories, we make use of short household panel surveys from 24 different countries. Unless stated otherwise, we make use of data for the period 2004-2011 for the estimation of the simulation parameters and use 2010 as the reference year for the simulations.

Table A1 in the Annex describes in detail the data sources used, the sample periods and any adjustments made to the data for each country in the sample. All datasets allow following individuals for at least three years.

19 These results reflect a mix of cohort and age effects, with the latter likely to prevail since mobility, as we will see, is much stronger for young workers than for prime age or older workers. 
For European countries except Germany, Switzerland and the United Kingdom, we make use of the longitudinal data of the European Survey of Income and Living Conditions (EU-SILC) for the period 2004-2011. For Germany, Switzerland and the United Kingdom, we make use of national sources in the form of, respectively, the German Socio-Economic Panel (GSOEP) and the Swiss Household Panel (SHP) and the British Household Panel Survey (BHPS). ${ }^{20}$ Data for the Slovak Republic end in 2010 and data for Sweden end in 2009. For the four non-European countries, we make use of national sources in the form of the Household, Income and Labour Dynamics in Australia (HILDA) survey for Australia, the Survey of Income and Program Participation (SIPP) for the United States, the Korean Labor and Income Panel Study and the Keio Household Panel for Japan.

The analysis makes use of the following information: monthly earnings in the previous year if employed (annual labour earnings divided by the number of months worked), education, potential experience (current age minus school-leaving age with the latter defined as in OECD, 2014) and gender. All information relates to the time of the interview unless specified otherwise. Individuals with missing information are dropped. The estimations focus on individuals aged 15-64 at any point in the sample (20-64 for Denmark and Japan). Students, apprentices, employees in armed forces, self-employed and inactive are dropped. Because of outliers with implausibly high or low earnings values, data are trimmed at the bottom and top $1 \%$ within each gender, education and potential experience group. Finally, only individuals with complete information for at least three consecutive observations are kept.

20 No data is available the longitudinal version of EU SILC version for Germany and Switzerland. While the United Kingdom is included, we make use of the British Household Panel Survey (BHPS) instead as the sample is much larger and the quality of the data much better. A drawback of the British Household Panel Survey (BHPS) is that it has been replaced by the UK Household Longitudinal Study (UKHLS) in 2009, which means that the latest year available for the United Kingdom is 2008 instead of 2011 as for the other countries. 


\subsection{Data on unemployment benefit coverage and generosity ${ }^{21}$}

Individual data on unemployment benefit (UB) coverage among the unemployed are obtained from the European Union Labour Force Survey (EU-LFS) for the European countries, Household, Income and Labour Dynamics (HILDA) for Australia, Keio Household Panel Survey (KHPS) for Japan, Korean Labor and Income Panel Study (KLIPS) for Korea, National labour force survey for Turkey and the Current Population Survey March supplement (CPS March) for the United States.

Data on unemployment benefit generosity are derived from the OECD's database on taxbenefit policies, which describes redistribution policies for working-age people and their families and allows for comparisons of income adequacy and work incentives over time and across countries. For the present purposes, the replacement rate is allowed to vary by decile of the previous wage and, hence, takes account of non-linearities in the replacement rate with respect to the previous wage. This is important because in most OECD countries unemployment benefits are capped at a given ceiling. Moreover, many countries apply declining replacement rates schedules to preserve work incentives over the duration of the unemployment spell.

\subsection{Validation}

Since the household panels used in this paper are not necessarily designed for the purposes of making cross-country comparisons of earnings inequality and unemployment, an external validation exercise is conducted to assess how well the data used can re-produce standardised

$21 \quad$ For descriptive statistics on UB coverage and generosity by country, see Garnero et al. (2016). 
indicators of inequality and unemployment that have been constructed by the OECD. The results are reported in Table A2 and suggest that the data used in this paper can reproduce the OECD measures of unemployment and inequality well. The internal validity of the simulated data is assessed by comparing the simulated values for inequality, unemployment and benefit coverage with those in the same year in the actual data. The results are reported in Table A3 and generally suggest a very good fit between the actual and the simulated data.

\section{Results}

\subsection{Results by country}

Table 3 provides a comprehensive picture of short-term earnings inequality, long-term earnings inequality and earnings mobility across $24 \mathrm{OECD}$ countries based on a consistent methodology and comparable data. Earnings inequality is measured in terms of the Gini, Theil, Mean Logarithmic Deviation, and the P80/P20 and P90/P10 percentile ratios. ${ }^{22}$ Earnings mobility is defined as the percentage reduction in short-term earnings inequality over time as a result of mobility (Shorrocks's mobility index). The measures over ten years relate to individuals aged 15 to 54 years old (20 to 54 for Denmark and Japan) in the reference year while the measures over 20 years focus on young persons aged 15-24 in the reference year (20-29 for Denmark and Japan). Since the latter focus on young people and cover the most important part of their career, at least in terms of mobility, these are used to provide a lower-bound estimate of the role of mobility for life-

22 A minimum income floor of $10 \%$ is imposed for those individuals who are unemployed and do not qualify for an unemployment benefit is imposed when computing the Theil index, the Mean Logarithmic Deviation, and the percentile ratios. This is necessary because these indices cannot be calculated in the presence of zero earnings. We run a sensitivity analysis to test that this choice does not affect our results (see Section 7). 
time inequality. Annex Table A5 provides similar results that focus on continuously employed persons and hence abstracts from movements between unemployment and employment. ${ }^{23}$

The results show that on average across the countries analysed mobility reduces earnings inequality by around $25 \%$ over the working life. This can be seen from the Gini index over 20 years which provides a crude indication of the role of mobility for inequality over the working life since it follows young persons during the first twenty years of their careers when mobility is most important. Results focusing only on continuously employed individuals, which abstract from movements in and out of employment, suggest that short-term and long-term earnings inequality are considerably lower than those for active individuals and that the proportional inequalityreducing effect of mobility is also substantially lower (about 15\%) (Table A5).

While these results indicate that short-term earnings inequality contains a sizeable transitory component, it also implies that the bulk of earnings inequality is permanent in nature. Long-term earnings inequality reflects structural differences in earnings which are determined by the structure of labour demand and supply, and the nature of policies and institutions.

\section{[Insert Table 3 here]}

\subsection{Results by socio-economic group}

Figure 2 documents how the importance of earnings mobility evolves over the life course by focusing on the Spearman rank correlation between earnings in a given year and long-term earnings across individuals. This correlation strengthens rapidly with age and peaks around 0.85

23 Rather than re-estimating the simulation parameters using a highly selected sample of persons who are continuously employed during the sample period this is done ex post by assuming that persons who are predicted to become unemployed remain in the current employment state. In terms of the transition matrix, this means that transitions in and out of unemployment are added to the diagonal elements of the matrix. 
when people are in their early forties and then remains persistently high until their late fifties. This implies that mobility is concentrated during the first decade of worker careers and that the relative earnings position for prime-age workers can be considered representative of their position in the distribution of life-time earnings. The concentration of mobility in the first decade of worker careers partly reflects the sorting of workers across high or low paying jobs. ${ }^{24}$

The same analysis by level of gender and education suggests that mobility for women is slightly higher than for men all at all ages. This is likely to reflect differences in labour market attachment and the importance of non-standard work among women, particularly part-time work. In terms of education, workers with low levels of education show relatively more mobility across the entire working life than workers with intermediate and high levels of educational attainment. This reflects the higher risk of becoming unemployed at each stage of their career.

\section{[Insert Figure 2 here]}

\section{The relationship between inequality and mobility}

\subsection{Cross-country evidence}

In order to provide a first indication of the relationship between inequality and mobility across countries, Table 3 also reports the correlation coefficients between earnings mobility and short-term inequality across countries (bottom row). It shows that the cross-country correlation depends on the measure of earnings inequality used, as was also suggested by Jäntti and Jenkins (2015). It tends to be weak and insignificant when focusing on measures of earnings inequality that consider the entire distribution such as the Gini, the Theil index or the Mean Logarithmic

\footnotetext{
$24 \quad$ Similar results are found by Guvenen et al. (2015) using data on millions of US workers over nearly 40
} years and by Bönke et al. (2015) who study lifetime earnings of men in Western Germany. 
Deviation, but positive and statistically significant when focusing on percentile ratios that consider only the tails of the distribution. ${ }^{25}$ If mobility is more positively correlated with indices focusing on the tails than with indices focusing on the middle of the distribution, this means that in countries with higher mobility there tends to be more earnings inequality in the bottom or the top of the distribution.

There is some indication that the positive relationship between inequality and mobility in the tails is mainly driven by employment mobility in the lower tail. This is based on two observations. First, Table 3 shows that the relationship between inequality and mobility is positive and statistically significant using P50/P10 but not when using P90/P50. Second, Table A5 in the Annex shows that when one abstracts from movements in and out of employment, the relationship between earnings mobility and inequality becomes negative or insignificant. ${ }^{26}$

In order to analyse the relationship between earnings inequality and mobility in more detail, it is important to look not just at the global level of mobility and inequality but also at their relationship along the entire earnings distribution. ${ }^{27} \mathrm{~A}$ straightforward way of doing this is to use the percentile ratios $\mathrm{P} 20 / \mathrm{P} 10, \mathrm{P} 30 / \mathrm{P} 20, \ldots, \mathrm{P} 90 / \mathrm{P} 10$ to characterise the relationship between short-term inequality and mobility along different segments of the distribution. Figure 3 shows respectively the short-term decile ratios on average across countries (Panel A), the corresponding mobility rates for each percentile ratio on average across countries (Panel B) and the correlation The results are unchanged when excluding countries one or two countries at a time. Somewhat similar results are found when focusing on cohorts aged 15-24 in 2010 over 20 years (see Garnero et al., 2016, for details). However, in this case, the positive relationship is also found in the top half of the distribution. This reflects the fact that employment mobility is important for young workers in general and not just those with low earnings

In a similar spirit, Schluter and Trede (2003) find that income mobility is larger in Germany than in the United States, because higher mobility in the bottom of the distribution in Germany is combined with an implicitly higher weighting by the mobility index at the bottom (inequality indices by construction do not give the same weight to the entire income spectrum). 
coefficients between the percentile ratios and the corresponding mobility measures across countries (Panel C).

On average across countries, short-term earnings inequality as measured by these percentiles ratios is broadly constant along the distribution on earnings, except for the first percentile ratio P20/P10 where it is somewhat higher (Panel A). Thus, earnings increase more or less proportionally along the distribution, consistent with the commonly used assumption that the distribution of earnings is log normal. This means that positional mobility requires increasingly large absolute changes in earnings the higher the level of earnings.

The equalising effect of mobility is strongly concentrated in the bottom of the distribution due to the importance of movements in and out of employment for long-term earnings inequality (Panel B). In part, this pattern is mechanical. The equalising effect of employment mobility would still be concentrated in the bottom of the distribution if the risk of unemployment were to be uniformly distributed among employed persons. The reason for this is that all such movements matter for long-term earnings in the bottom of the distribution but only those involving high-wage earnings have an equalising impact in the top of the distribution. However, the equalising effect of employment mobility also depends on many country-specific factors such as the level of unemployment, the degree of unemployment turnover and the effectiveness of unemployment insurance systems in sustaining incomes during periods of unemployment.

The correlation between earnings mobility and short-term inequality across countries is positive and statistically significant in the bottom of the earnings distribution, and not significantly different from zero in the rest of the distribution (Panel C). The positive correlation in the bottom of the distribution reflects the greater importance of employment mobility in 
countries with more inequality in the bottom of the earnings distribution. If we exclude employment mobility, as is done in Figure A2 in the Annex, the positive relationship at the bottom disappears while the correlations in the upper parts of the distribution remain largely the same.

\section{[Insert Figure 3 here]}

These results provide two important insights. First, earnings mobility and inequality do not always go hand-in-hand as is often suggested in the popular discourse. Second, higher employment mobility, i.e. movements in and out of employment, in the bottom of the distribution is associated with more earnings inequality. Since individuals in the $10^{\text {th }}$ or particularly the $20^{\text {th }}$ percentile of the earnings distribution are employed in the large majority of countries, this tends to reflect more inequality in earnings among employed workers. ${ }^{28}$

\subsection{Accounting for group effects}

This sub-section analyses to what extent the relationship between earnings mobility and inequality is driven by particular workforce groups. Earnings mobility consists both of betweengroup mobility, which is largely related to expected changes in earnings based on one's groupspecific earnings-experience profile, and within-group mobility, which relates largely to the unpredictable components of earning mobility.

Table 4 decomposes earnings inequality and mobility within and between groups on average across countries. The decomposition considers 24 groups according to gender, age (four 10-year groups) and education (three groups). Inequality is measured using the Theil index and the Mean

28 For the same reason, this finding is unlikely to be driven by the negative relationship between the generosity of unemployment benefits and unemployment turnover. 
Logarithmic Deviation since, unlike the Gini and percentiles ratios, these belong to the class of generalised entropy indices which are additively decomposable across sub-groups. Since the Theil index and Mean Logarithmic Deviation require positive earnings, zero earnings for unemployed persons without benefits are replaced by a value of $10 \%$ of the country median (as shown in the sensitivity analysis, this has no impact on the qualitative results).

The results show that mobility is largely concentrated within groups (around 90\% on average) and hence reduces within-group earnings inequality more than inequality between groups. The cross-country correlation between short-term earnings inequality and mobility within and between groups is mostly insignificant. If anything, the positive relationship is driven by the within-group component, i.e. the part that relates largely to the unpredictable components of earning mobility.

\section{[Insert Table 4 here]}

Finally, repeating the same analysis of the relationship between earnings inequality and mobility across countries (cf. Figure 3) for different groups of workers suggests that the monotonic decline over the distribution carries through within individual groups. Table 5 shows that differences by gender and age groups are very small while the differences by education groups are larger, but still reveal a weak declining pattern (see Table A6 in the Annex for employed only). The correlation between earnings inequality and mobility in the bottom of the distribution is positive and statistically significant for all groups. In the case of low skilled workers, the positive correlation can be found also higher in the distribution, reflecting to the more pervasive risk of unemployment among low-skilled workers at each stage of their career. In conclusion, there is 
little indication that the relationship between earnings inequality and mobility differs strongly across groups. ${ }^{29}$

\section{[Insert Table 5 here]}

\subsection{Sensitivity analysis}

Annex IV provides a detailed assessment of the sensitivity of the baseline results to changes in the simulation procedure comparing the baseline results with those that are obtained by changing one feature of the simulation procedure at a time. The sensitivity analysis shows that alternative specifications may in some cases slightly change the specific estimates of short-term, long-term inequality and mobility (in all cases in the expected direction) but never affect the main conclusions. Importantly, it shows that the correlation between short-term earnings inequality and mobility does not depend on the specific way the simulation procedure was implemented. The correlation coefficient between inequality and mobility with the Gini index is statistically insignificant in all cases. The correlation coefficient with the P90/P10 ratio is positive and statistically significant in all cases except when hourly instead of monthly earnings are used.

\section{Conclusions}

Over the past years the perception that inequality is rising and upward mobility stalling has come under the spotlight in many OECD countries and has become the subject of fierce political discussions. A specific debate has focused on the link between inequality and mobility across the

29 However, the welfare implications of employment mobility are likely to differ across workforce groups. Being in the bottom of the distribution is likely to be a temporary status for many young people who will rapidly move up to better jobs in the first years of their careers. Higher mobility at the bottom tail of the distribution therefore represents higher hopes of upward mobility for young people. The same may not apply to unskilled workers who experience high employment mobility, i.e. in and out of employment, but little mobility up the earnings ladder. In this case, mobility will still have an equalising effect but just among those in the bottom of the distribution. 
working life and across generations. A widespread belief states that a more unequal distribution of earnings is the price to pay for more opportunities across the working life and across generations. Existing empirical studies have tended to focus on comparisons between the United States and a handful of European countries, notably because of the lack of comparable data, and have provided only mixed support for this belief.

The main contribution of this paper is to provide for the first time comprehensive evidence across a large number of advanced economies on the importance of intra-generational mobility and its relationship with earnings inequality. It does so by adapting and extending the simulation methodology proposed by Bowlus and Robin (2012) to generate individual earnings and employment trajectories in the longer term using short panel data for 24 OECD countries. A validation exercise using social security data for Italy shows that this approach captures the observed evolution of earnings and, particularly, the degree of mobility rather well. The evidence provided in this paper provides two key insights:

- Taking account of intra-generational mobility does not have major implications for assessing the depth of earnings inequalities. This means that countries with high inequalities at a point in time most often also tend to have high inequalities in terms of life-time earnings. This conclusion is based on two important findings. The first is that intra-generational mobility is not sufficiently important to equalise earnings differences that exist across individuals within a given year over the life-time. The bulk of earnings inequality at a given time is permanent. The second is that the results offer only mild and qualified support for the belief that higher earnings inequality is consistently associated with higher intra-generational mobility. While some countries, such as the United States, exhibit both relatively high inequality and mobility levels, other countries combine high 
inequality with low levels of mobility (e.g. Japan) or vice versa. The absence of a clearcut relationship between earnings inequality and mobility across countries suggests that policies and institutions can give rise to different combinations of inequality and mobility.

- To the extent that there is a positive relationship between inequality and intragenerational mobility this tends to be driven by employment mobility (movements between employment and unemployment) and inequality in the bottom of the distribution. This most likely reflects the role of policies and institutions for wage compression in the bottom of the distribution and employment mobility. ${ }^{30}$ Policies and institutions such as unemployment benefits, statutory minimum wages and collective wage agreements effectively impose wage floors and, as a result, have a tendency to lead to a more compressed wage distribution. In doing so, these institutions also make it harder for individuals to escape unemployment and hence reduce employment mobility. In countries where such institutions are weak, unemployed workers may find jobs more easily but these jobs tend to be less well paid and less secure since due to the weaker bargaining position of unemployed persons. ${ }^{31}$

The present results qualify previous findings by Bowlus and Robin (2012) who find, using a sample of five countries, that earnings mobility is positively correlated with base-year inequality

Previous research has found that institutions play a particularly important role in shaping inequalities in the bottom of the distribution (see among others Autor et al., 2014; Firpo et al., 2011; Machin, 1997; Nickell and Layard, 1999) as well as for unemployment turnover, particularly through their impact on the unemployment outflow rate (Murtin et al., 2014).

An alternative explanation could be that in countries with more dispersion in the bottom of the distribution workers face stronger incentives for moving between jobs. To the extent that such job-to-job flows tend to be associated with intermediate spells of unemployment (as contracts may not always connect exactly), higher job mobility in the bottom could be associated with more employment mobility. However, since this explanation assumes that job mobility is driven by differences in wages, one would expect observing a similar relationship between earnings inequality and mobility when focusing exclusively on continuously employed workers. Since this is not the case we do not view this as a good explanation.
} 
when earnings inequality. The analysis presented here suggest that these results hinge to an important extent on the measure of inequality used and, specifically, the use of measures that focus on the tails of the distribution. Moreover, the positive relationship between earnings inequality and mobility, which is found when focusing on the tails of the distribution, is driven by the relationship between inequality in the bottom of the distribution and movements between employment and unemployment. 


\section{REFERENCES}

Aaberge, Rolf, and Magne Mogstad, "Inequality in Current and Lifetime Income," Discussion Papers No. 726 Research Department of Statistics Norway (2012).

Aaberge, Rolf, Anders Björklund, Markus Jäntti, Marten Palme, Peder J. Pedersen, Nina Smith and Tom Wennemo, "Income Inequality and Income Mobility in the Scandinavian Countries Compared to the United States," Review of Income and Wealth 48, no. 4 (2002), 443-469.

Autor, David H., Alan Manning and Christopher L. Smith, "The Contribution of the Minimum Wage to U.S. Wage Inequality Over Three Decades: A Reassessment," NBER Working Paper No. 16533 (2014).

Bayaz-Ozturk, Gulgun, Richard Burkhauser and Kenneth Couch, "Consolidating the Evidence on Income Mobility in the Western States of Germany and the U.S. from 1984-2006," NBER Working Papers No. 18618 (2012).

Benabou, Roland and Efe A. Ok, "Social Mobility and the Demand For Redistribution: the Poum Hypothesis," The Quarterly Journal of Economics 116, no. 2 (2001), 447-487.

Bjorklund, Anders, “A Comparison between Actual Distributions of Annual and Lifetime Income: Sweden 1951-89," Review of Income and Wealth 39, no. 4 (1993), 377-386. 
Bönke, Timm, Giacomo Corneo and Holger Lüthen, "Lifetime Earnings Inequality in Germany," Journal of Labour Economics 33, no. 1 (2015), 171-208.

Bowlus, Audra and Jean-Marc Robin, "Twenty Years of Rising Inequality in US Lifetime Labor Income Values," Review of Economic Studies 71, no. 3 (2004), 709-742.

Bowlus, Audra and Jean-Marc Robin, “An International Comparison Of Lifetime Inequality: How Continental Europe Resembles North America," Journal of the European Economic Association 10, no. 6 (2012), 1236-1262.

Buchinsky, Moshe and Jennifer Hunt, "Wage Mobility In The United States," The Review of Economics and Statistics 81, no. 3 (1999), 351-368.

Burkhauser, Richard and John Poupore, “A Cross-National Comparison Of Permanent Inequality In The United States And Germany," Review of Economics and Statistics 79, no. 1 (1997), $10-17$.

De Tocqueville, Alexis, De la démocratie en Amérique, Éditions Gallimard (1835).

Firpo, Sergio, Nicole Fortin and Thomas Lemieux, "Occupational Tasks, and Changes in the Wage Structure," IZA Discussion Papers, no. 5542 (2011).

Flinn, Christopher, "Labour Market Structure and Inequality: A Comparison of Italy and the U.S.," Review of Economic Studies 69, (2002) 611-645.

Garnero, Andrea, Alexander Hijzen and Sébastien Martin, "More unequal, but more mobile? Earnings inequality and mobility in OECD countries," OECD Social, Employment and Migration Working Papers 177 (2016). 
Gottschalk, Peter and Mihn Huynh, “Are Earnings Inequality and Mobility Overstated? The Impact of Non-Classical Measurement Error," Review of Economics and Statistics 92 (2010), 302-315.

Guvenen, Fatih, Fatih Karahan, Serdar Ozkan and Jae Song, "What Do Data on Millions of U.S. Workers Reveal about Life-Cycle Earnings Risk?” Federal Reserve Bank of New York Staff Report No. 710 (2015).

Jäntti, Markus and Stephen P. Jenkins, "Income Mobility," Chapter 10 in A.B. Atkinson and F. Bourguignon (eds.), Handbook of Income Distribution 2 (2015), Elsevier.

Kopczuk, Wojciech, Emmanuel Saez and Jae Song, "Earnings Inequality and Mobility in the United States: Evidence from Social Security Data since 1937," Quarterly Journal of Economics 125, no. 1 (2010), 91-128.

Krueger, Alan B., “The Rise and Consequences of Inequality,” Speech at the Center for American Progress (January 12, 2012).

Machin, Steve, "The Decline of Labour Market Institutions and the Rise in Wage Inequality in Britain,” European Economic Review 41/3-5 (1997), 647-657.

MaCurdy, Thomas, “A Practitioner's Approach to Estimating Intertemporal Relationships Using Longitudinal Data: Lessons from Applications in Wage Dynamics,” in J. Heckman and E. Leamer (eds.), Handbook of Econometrics 6A, (2007), Elsevier.

Murtin, Fabrice, Alain de Serres and Alexander Hijzen, "Unemployment and the coverage extension of collective wage agreements," European Economic Review 71(C) (2014), 52-66. 
Nickell, Stephen and Richard Layard, "Labour Market Institutions and Economic Performance," in O. Ashenfelter and D. Card (eds.), Handbook of Labor Economics 3, (1999) Elsevier.

OECD, OECD Employment Outlook 1997, OECD Publishing (1997), Paris.

OECD, Education at a Glance 2014, OECD Publishing (2014), Paris.

Piketty, Thomas, "Social mobility and redistributive politics," The Quarterly Journal of Economics 110, no. 3 (1995), 551-584.

Schluter, Christian and Mark Trede, “Local versus Global Assessment of Mobility,” International Economic Review 44, no.4 (2003), 1313-1335.

Shorrocks, Anthony F., "Income Inequality and Income Mobility," Journal of Economic Theory 19, no. 2 (1978), 376-393.

Waajers, Rob and Marcel Lever, "Inkomen en netto profijt van sociale zekerheid gedurende de levensloop: Uitkomsten van een TRAIL" [Transities van Inkomens tijdens de Levensloop], CPB achtergronddocument (2013). 


\section{FIGURES AND TABLES}

Table 1. Rank correlations of year-to-year earnings immobility in the actual and simulated data Spearman's rank correlation between individual earnings in 2003 and 2004 conditional on initial earnings decile

\begin{tabular}{c|cccc}
\hline Deciles & Actual & OLS simulation & $\begin{array}{c}\text { Fixed effects } \\
\text { simulation }\end{array}$ & $\begin{array}{c}\text { Dynamic } \\
\text { simulation }\end{array}$ \\
\hline D1 & 0.23 & 0.35 & 0.71 & 0.40 \\
D2 & 0.35 & 0.26 & 0.42 & 0.32 \\
D3 & 0.32 & 0.21 & 0.18 & 0.27 \\
D4 & 0.33 & 0.21 & 0.13 & 0.26 \\
D5 & 0.29 & 0.21 & 0.14 & 0.28 \\
D6 & 0.35 & 0.20 & 0.15 & 0.30 \\
D7 & 0.39 & 0.24 & 0.15 & 0.23 \\
D8 & 0.47 & 0.33 & 0.19 & 0.30 \\
D9 & 0.61 & 0.42 & 0.36 & 0.46 \\
D10 & 0.85 & 0.69 & 0.71 & 0.67 \\
\hline $\begin{array}{l}\text { Average correlation } \\
\text { Average absolute deviation } \\
\text { from actual correlation }\end{array}$ & $\mathbf{0 . 4 2}$ & $\mathbf{0 . 3 1}$ & $\mathbf{0 . 3 2}$ & $\mathbf{0 . 3 5}$ \\
$\begin{array}{l}\text { Average deviation over the } \\
\text { actual average correlation }\end{array}$ & - & $\mathbf{0 . 1 2}$ & $\mathbf{0 . 1 6}$ & $\mathbf{0 . 1 2}$ \\
\hline
\end{tabular}

Source: Authors' estimates based on INPS data. 
Table 2. Rank correlations of long-term earnings immobility in the actual and simulated data

Spearman's rank correlation between individual earnings in Period 1 and Period 2 conditional on initial earnings decile

A. Three-year window (2003-06)

\begin{tabular}{|c|c|c|c|c|c|c|c|c|c|c|c|c|c|}
\hline & $\mathrm{D} 1$ & D2 & D3 & D4 & D5 & D6 & D7 & D8 & D9 & D10 & Av erage correlation & $\begin{array}{c}\text { Av erage absolute } \\
\text { deviation from } \\
\text { actual correlation }\end{array}$ & $\begin{array}{l}\text { Average deviation } \\
\text { over the actual } \\
\text { av erage correlation }\end{array}$ \\
\hline Actual & 0.08 & 0.20 & 0.21 & 0.19 & 0.21 & 0.23 & 0.23 & 0.33 & 0.45 & 0.76 & 0.29 & - & - \\
\hline OLS simulation & 0.13 & 0.10 & 0.08 & 0.07 & 0.14 & 0.13 & 0.13 & 0.17 & 0.23 & 0.48 & 0.17 & 0.11 & 0.39 \\
\hline Fixed effects simulation & 0.67 & 0.37 & 0.15 & 0.10 & 0.08 & 0.13 & 0.13 & 0.14 & 0.31 & 0.65 & 0.27 & 0.16 & 0.54 \\
\hline Dynamic simulation & 0.21 & 0.18 & 0.13 & 0.12 & 0.15 & 0.17 & 0.11 & 0.17 & 0.30 & 0.48 & 0.20 & 0.11 & 0.38 \\
\hline \multicolumn{14}{|c|}{ B. Six-year window (2003-09) } \\
\hline & D1 & D2 & D3 & D4 & D5 & D6 & D7 & D8 & D9 & D10 & Av erage correlation & $\begin{array}{c}\text { Av erage absolute } \\
\text { deviation from } \\
\text { actual correlation }\end{array}$ & $\begin{array}{l}\text { Av erage deviation } \\
\text { over the actual } \\
\text { av erage correlation }\end{array}$ \\
\hline Actual & 0.06 & 0.09 & 0.11 & 0.12 & 0.13 & 0.16 & 0.15 & 0.21 & 0.32 & 0.65 & 0.20 & - & - \\
\hline OLS simulation & 0.08 & 0.05 & 0.03 & 0.04 & 0.08 & 0.07 & 0.08 & 0.11 & 0.14 & 0.39 & 0.11 & 0.10 & 0.48 \\
\hline Fix ed effects simulation & 0.62 & 0.32 & 0.13 & 0.09 & 0.08 & 0.09 & 0.11 & 0.11 & 0.28 & 0.61 & 0.24 & 0.15 & 0.74 \\
\hline Dynamic simulation & 0.09 & 0.10 & 0.07 & 0.06 & 0.08 & 0.12 & 0.09 & 0.13 & 0.21 & 0.38 & 0.13 & 0.09 & 0.47 \\
\hline \multicolumn{14}{|c|}{ C. Nine-year window (2003-12) } \\
\hline & D1 & D2 & D3 & D4 & D5 & D6 & D7 & D8 & D9 & D10 & Av erage correlation & $\begin{array}{c}\text { Av erage absolute } \\
\text { deviation from } \\
\text { actual correlation }\end{array}$ & $\begin{array}{l}\text { Av erage deviation } \\
\text { over the actual } \\
\text { av erage correlation }\end{array}$ \\
\hline Actual & 0.04 & 0.07 & 0.10 & 0.09 & 0.08 & 0.13 & 0.13 & 0.17 & 0.27 & 0.57 & 0.16 & - & - \\
\hline OLS simulation & 0.08 & 0.05 & 0.02 & 0.04 & 0.04 & 0.04 & 0.05 & 0.08 & 0.08 & 0.34 & 0.08 & 0.09 & 0.53 \\
\hline Fixed effects simulation & 0.60 & 0.29 & 0.10 & 0.07 & 0.07 & 0.11 & 0.10 & 0.09 & 0.23 & 0.56 & 0.22 & 0.14 & 0.82 \\
\hline Dynamic simulation & 0.07 & 0.07 & 0.06 & 0.04 & 0.07 & 0.09 & 0.06 & 0.09 & 0.17 & 0.34 & 0.11 & 0.08 & 0.52 \\
\hline
\end{tabular}

Source: Authors' estimates based on Italian INPS data for 2003-12. 
Table 3. Short-term earnings inequality, long-term earnings inequality and earnings mobility across countries

Based on simulations over ten or twenty yearsa

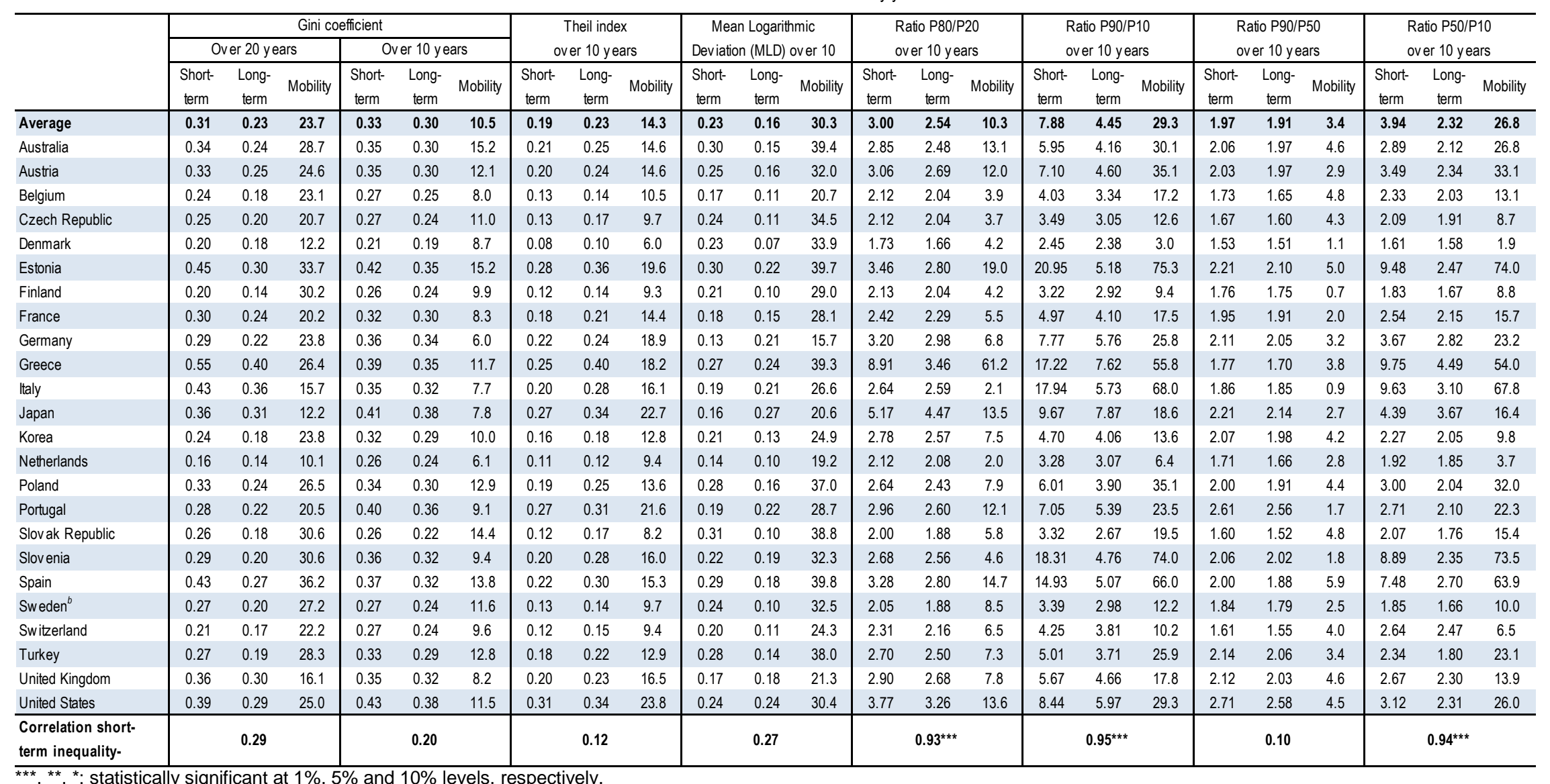

***,***; statistically significant at $1 \%, 5 \%$ and $10 \%$ levels, respectively.

a) Simulations are based on individuals aged 15 to 54 in the reference year and aged 15-24 for active persons over 20 years (aged 20-54 and 20-29 for Denmark and Japan). b) Results based on annual earnings.

Source: Authors' calculations based on the European Union Statistics on Income and Living Conditions (EU-SILC) for European countries and Turkey, Household, Income and Labour

Dynamics (HILDA) for Australia, German Socio-Economic Panel (GSOEP) for Germany, Keio Household Panel Survey (KHPS) for Japan, Korean Labor and Income Panel Study

(KLIPS) for Korea, Swiss Household Panel (SHP) for Switzerland and Survey of Income and Program Participation (SIPP) for the United States. 
Table 4. Within and between short and long term earnings inequality and within and between mobility On average across countries

\begin{tabular}{l|ccc|ccc}
\hline & \multicolumn{3}{|c|}{ Theil index } & \multicolumn{3}{c}{ Mean Logarithmic Deviation (MLD) } \\
\cline { 2 - 7 } & Total & Within & Between & Total & Within & Between \\
\hline Short term inequality & 0.19 & $70.1 \%$ & $29.9 \%$ & 0.23 & $75.2 \%$ & $24.8 \%$ \\
Long term inequality & 0.14 & $62.6 \%$ & $37.4 \%$ & 0.16 & $65.6 \%$ & $34.4 \%$ \\
Mobility & 0.22 & $79.9 \%$ & $20.1 \%$ & 0.30 & $80.9 \%$ & $19.1 \%$ \\
$\begin{array}{l}\text { Correlation short-term } \\
\text { inequality-mobility }\end{array}$ & $\mathbf{0 . 1 2}$ & $\mathbf{0 . 3 4}$ & $\mathbf{- 0 . 2 1}$ & $\mathbf{0 . 2 7}$ & $\mathbf{0 . 4 8}$ & $\mathbf{- 0 . 3 3}$ \\
\hline
\end{tabular}

${ }^{* * *},{ }^{* *},{ }^{*}$ : statistically significant at $1 \%, 5 \%$ and $10 \%$ levels, respectively.

Source: Authors' calculations based on the European Union Statistics on Income and Living Conditions (EU-SILC) for European Union countries and Turkey, Household, Income and Labour Dynamics (HILDA) for Australia, British Household Panel (BHPS) for the United Kingdom, German Socio-Economic Panel (GSOEP) for Germany, Keio Household Panel Survey (KHPS) for Japan, Korean Labor and Income Panel Study (KLIPS) for Korea, Swiss Household Panel (SHP) for Switzerland and Survey of Income and Program Participation (SIPP) for the United States. 
Table 5. Correlations between short-term earnings inequality and earnings mobility across the distribution by groups

On average across countries

\begin{tabular}{|c|c|c|c|c|c|c|c|c|c|c|c|c|c|c|c|c|c|c|}
\hline $\begin{array}{l}\text { Percentile } \\
\text { ratio }\end{array}$ & Total & & Men & & Women & & Youth & & $\begin{array}{c}\text { Prime } \\
\text { Age }\end{array}$ & & $\begin{array}{c}\text { Older } \\
\text { workers }\end{array}$ & & $\begin{array}{l}\text { Low- } \\
\text { skilled }\end{array}$ & & $\begin{array}{l}\text { Medium } \\
\text {-skilled }\end{array}$ & & $\begin{array}{l}\text { High- } \\
\text { skilled }\end{array}$ & \\
\hline P20/P10 & 0.96 & $* * *$ & 0.95 & $* * *$ & 0.83 & $* * *$ & 0.70 & $* * *$ & 0.97 & & 0.95 & $* * *$ & 0.70 & $* * *$ & 0.87 & $* * *$ & 0.68 & $* * *$ \\
\hline P30/P20 & 0.99 & $* * *$ & 0.97 & $* * *$ & 0.99 & $* * *$ & 0.84 & $* * *$ & 0.90 & $* * *$ & 0.95 & $* * *$ & 0.76 & $* * *$ & 0.97 & $* * *$ & 0.81 & $* * *$ \\
\hline P40/P30 & 0.29 & & 0.64 & $* * *$ & 0.29 & & 0.96 & $* * *$ & 0.26 & & 0.65 & $* * *$ & 0.96 & $* * *$ & 0.78 & $* * *$ & 0.02 & \\
\hline P50/P40 & 0.57 & $* * *$ & 0.11 & & 0.35 & * & 0.94 & $* * *$ & 0.53 & $* * *$ & 0.64 & $* * *$ & 0.62 & $* * *$ & 0.36 & * & -0.26 & \\
\hline P60/P50 & 0.23 & & 0.12 & & -0.29 & & 0.91 & $* * *$ & 0.06 & & 0.46 & ** & 0.96 & $* * *$ & 0.08 & & 0.28 & \\
\hline P70/P60 & -0.16 & & -0.15 & & -0.19 & & 0.07 & & -0.04 & & -0.19 & & 0.87 & $* * *$ & 0.54 & $* * *$ & -0.21 & \\
\hline P80/P70 & 0.31 & & 0.01 & & 0.37 & * & -0.06 & & 0.21 & & 0.05 & & -0.05 & & -0.44 & ** & -0.05 & \\
\hline P90/P80 & -0.22 & & -0.03 & & 0.07 & & 0.05 & & -0.16 & & -0.15 & & 0.27 & & -0.39 & * & -0.04 & \\
\hline
\end{tabular}

***, **, *: statistically significant at $1 \%, 5 \%$ and $10 \%$ levels, respectively.

Source: Authors' calculations based on the European Union Statistics on Income and Living Conditions (EU-SILC) for European Union countries and Turkey, Household, Income and Labour Dynamics (HILDA) for Australia, British Household Panel (BHPS) for the United Kingdom, German Socio-Economic Panel (GSOEP) for Germany, Keio Household Panel Survey (KHPS) for Japan, Korean Labor and Income Panel Study (KLIPS) for Korea, Swiss Household Panel (SHP) for Switzerland and Survey of Income and Program Participation (SIPP) for the United States. 
Figure 1. Shorrocks' mobility index in the actual and simulated data

Percentage reduction in earnings inequality when averaging earnings over time

$$
\text { -----OLS } \quad \text {-........ Fixed effects - Dynamic - Actual }
$$

A. Mobility over two to ten years, 2003-12

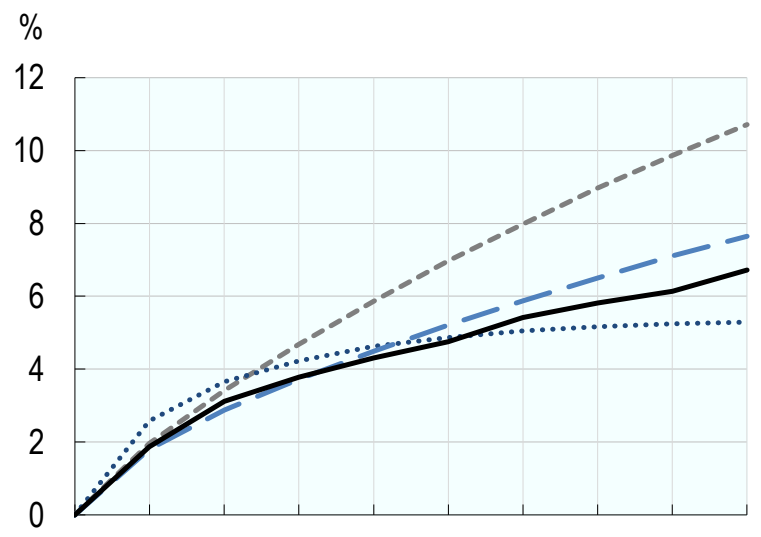

2003200420052006200720082009201020112012
B. Ten-year mobility by birth cohort, 1948-84

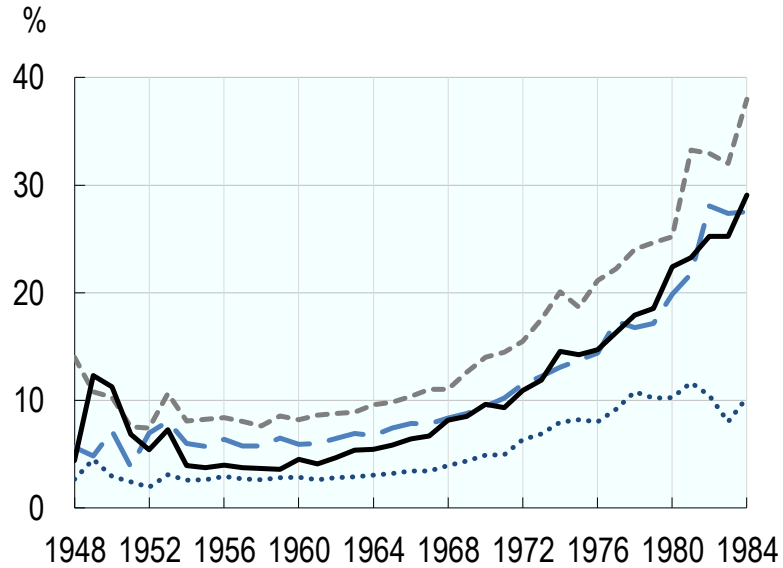

Source: Authors' estimates based on Italian INPS data for 2003-12. 
Figure 2. Rank correlations between short-term and long-term earnings by gender and education

On average across countries

A. Gender

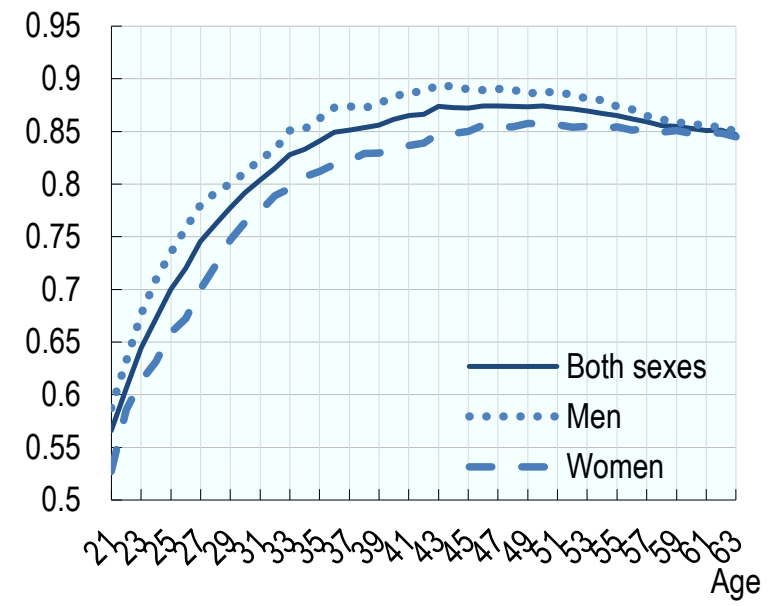

B. Educational attainment

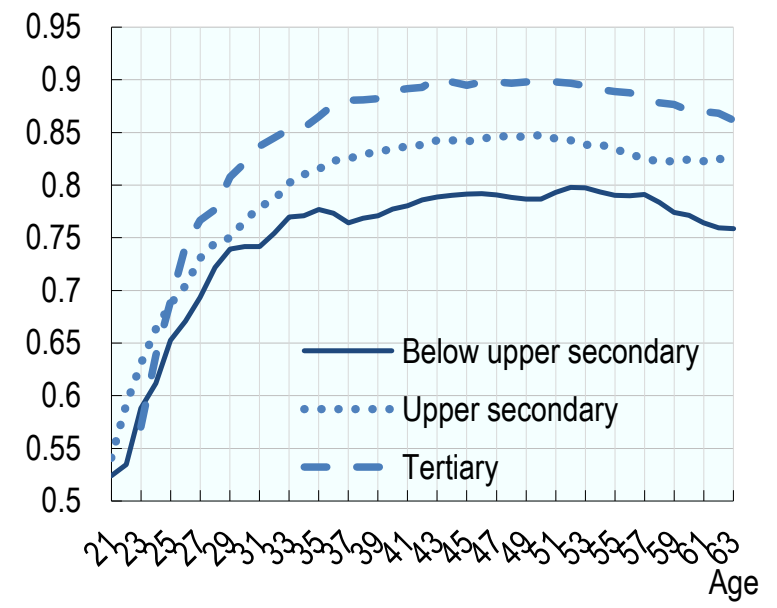

Source: Authors' calculations based on the European Union Statistics on Income and Living Conditions (EU-SILC) for European Union countries and Turkey, Household, Income and Labour Dynamics (HILDA) for Australia, British Household Panel (BHPS) for the United Kingdom, German Socio-Economic Panel (GSOEP) for Germany, Keio Household Panel Survey (KHPS) for Japan, Korean Labor and Income Panel Study (KLIPS) for Korea, Swiss Household Panel (SHP) for Switzerland and Survey of Income and Program Participation (SIPP) for the United States. 
Figure 3. Earnings inequality, mobility and the correlation between inequality and mobility across the distribution

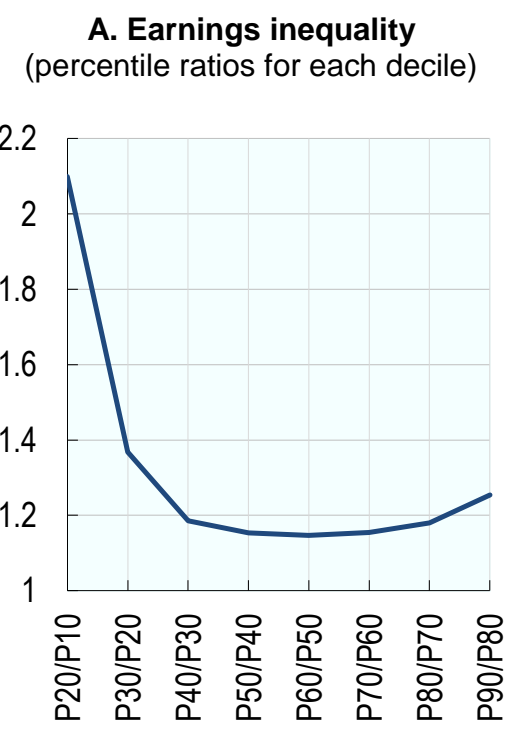

\section{B. Earnings mobility (Shorrocks index for each decile)}

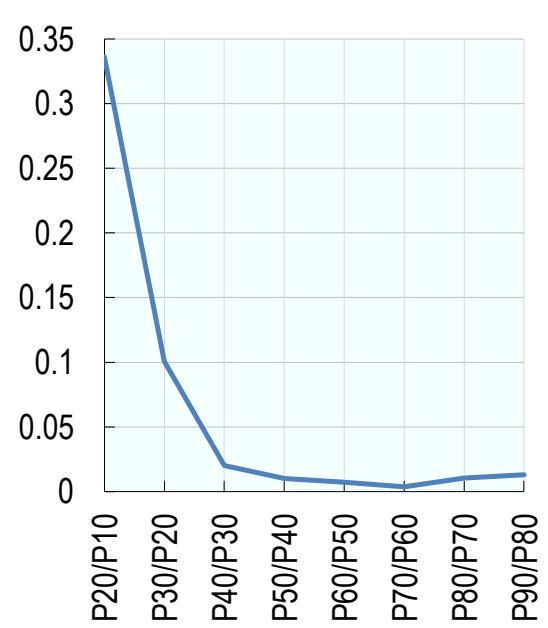

\section{Correlation mobility-inequality} in each decile

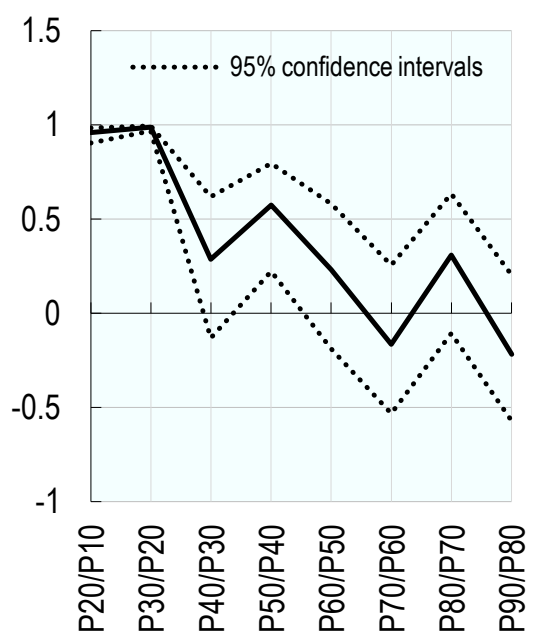

Source: Authors' calculations based on the European Union Statistics on Income and Living Conditions (EU-SILC) for European Union countries and Turkey, Household, Income and Labour Dynamics (HILDA) for Australia, British Household Panel (BHPS) for the United Kingdom, German Socio-Economic Panel (GSOEP) for Germany, Keio Household Panel Survey (KHPS) for Japan, Korean Labor and Income Panel Study (KLIPS) for Korea, Swiss Household Panel (SHP) for Switzerland and Survey of Income and Program Participation (SIPP) for the United States. 
ANNEX (NOT FOR PUBLICATION) 


\section{ANNEX I: FURTHER INFORMATION ON DATA USED}

\section{AI.1 Data sources and descriptive statistics}

\begin{tabular}{|c|c|c|c|c|c|c|c|c|c|c|c|}
\hline \multirow[b]{2}{*}{ Country } & \multicolumn{2}{|c|}{ Survey description } & \multicolumn{2}{|c|}{ Estimations } & \multicolumn{3}{|l|}{ Annual earnings } & \multirow[b]{2}{*}{$\begin{array}{l}\text { Number of months } \\
\text { worked }\end{array}$} & \multirow[b]{2}{*}{ Hours worked } & \multirow[b]{2}{*}{$\begin{array}{l}\text { Monthly earnings } \\
\text { calculation }\end{array}$} & \multirow[b]{2}{*}{$\begin{array}{l}\text { Hourly earnings } \\
\text { calculation }\end{array}$} \\
\hline & Name & Sample & \begin{tabular}{|c|} 
Transitions \\
Period \& \\
Sample size \\
\end{tabular} & $\begin{array}{l}\text { Simulations } \\
\text { Ref. year \& } \\
\text { Sample size }\end{array}$ & Description & Freq. & $\begin{array}{c}\text { Wage } \\
\text { supplements } \\
\text { (bonus, tips, }\end{array}$ & & & & \\
\hline Australia & $\begin{array}{l}\text { Household, Income } \\
\text { and Labour } \\
\text { Dynamics in } \\
\text { Australia (HILDA) }\end{array}$ & $\begin{array}{l}\text { Persons aged } \\
15-54 \text { in the } \\
\text { reference year }\end{array}$ & $\begin{array}{r}2004-11 \\
83,463\end{array}$ & $\begin{array}{l}2010 \\
5,579\end{array}$ & $\begin{array}{l}\text { Imputed financial year gross wages and salary } \\
\text { (includes incorporated business wages and } \\
\text { salary) }\end{array}$ & Annual & Yes & $\begin{array}{l}\text { Per cent time spent in jobs } \\
\text { in last financial year, } \\
\text { derived from the calendar. }\end{array}$ & $\begin{array}{l}\text { Hours per week usually } \\
\text { worked in main job }\end{array}$ & $\begin{array}{l}\text { Annual earnings } \\
\text { divided by the } \\
\text { number of months } \\
\text { worked }\end{array}$ & $\begin{array}{l}\text { Monthly eamings } \\
\text { divided by the usual } \\
\text { weekly hours worked } \\
\text { (multiplied by 52/12) }\end{array}$ \\
\hline Germany & $\begin{array}{l}\text { German Socio- } \\
\text { Economic Panel } \\
\text { Study (SOEP) }\end{array}$ & $\begin{array}{l}\text { Persons aged } \\
15-54 \text { in the } \\
\text { reference year }\end{array}$ & $\begin{array}{r}2004-11 \\
70,989\end{array}$ & $\begin{array}{l}2010 \\
5,171\end{array}$ & $\begin{array}{l}\text { Sum of the gross amount of wages and salary } \\
\text { (main and second job), 13th and 14th month } \\
\text { pay, Christmas, vacation, profit-sharing and } \\
\text { other bonuses received last year }\end{array}$ & Annual & Yes & $\begin{array}{l}\text { Months of worked in the } \\
\text { main and second job last } \\
\text { year }\end{array}$ & $\begin{array}{l}\text { Agreed weekly working } \\
\text { hours. } \\
\text { This variable is designed to } \\
\text { offer annual data on agreed } \\
\text { weekly working hours. }\end{array}$ & $\begin{array}{l}\text { Annual earnings } \\
\text { divided by the } \\
\text { number of months } \\
\text { worked }\end{array}$ & \begin{tabular}{|l} 
Monthly eamings \\
divided by the usual \\
weekly hours worked \\
(multiplied by 52/12)
\end{tabular} \\
\hline Japan & $\begin{array}{l}\text { Keio Household } \\
\text { Panel Survey } \\
\text { (KHPS) }\end{array}$ & $\begin{array}{l}\text { Persons aged } \\
20-54 \text { in the } \\
\text { reference year }\end{array}$ & $\begin{array}{r}2004-11 \\
21,168\end{array}$ & $\begin{array}{l}2010 \\
1,346\end{array}$ & $\begin{array}{l}\text { Annual labor income, last year (ten thousand } \\
\text { yen) }\end{array}$ & Annual & Yes & $\begin{array}{l}\text { Months worked last years } \\
\text { derived from the status in } \\
\text { employment each year } \\
\text { during last year }\end{array}$ & $\begin{array}{l}\text { Usual hours worked per } \\
\text { week }\end{array}$ & $\begin{array}{l}\text { Annual earnings } \\
\text { divided by the } \\
\text { number of months } \\
\text { worked }\end{array}$ & $\begin{array}{l}\text { Monthly earnings } \\
\text { divided by the usual } \\
\text { weekly hours worked } \\
\text { (multiplied by 52/12) }\end{array}$ \\
\hline Korea & $\begin{array}{c}\text { Korean Labor and } \\
\text { Income Panel Study } \\
\text { (KLIPS) }\end{array}$ & $\begin{array}{l}\text { Persons aged } \\
15-54 \text { in the } \\
\text { reference year }\end{array}$ & $\begin{array}{r}2004-11 \\
49,878\end{array}$ & $\begin{array}{r}2010 \\
3,272\end{array}$ & Nominal monthly earnings (incl. overtime) & Monthly & Yes & & $\begin{array}{l}\text { Average weekly work } \\
\text { hours for employees } \\
\text { working on an irregular } \\
\text { working-time schedule and } \\
\text { regular weekly work hours }\end{array}$ & - & \begin{tabular}{|l} 
Monthly earnings \\
divided by the usual \\
weekly hours worked \\
(multiplied by 52/12)
\end{tabular} \\
\hline Switzerland & $\begin{array}{l}\text { Swiss Household } \\
\text { Panel (SHP) }\end{array}$ & $\begin{array}{l}\text { Persons aged } \\
15-54 \text { in the } \\
\text { reference year }\end{array}$ & $\begin{array}{r}2004-11 \\
23,493\end{array}$ & $\begin{array}{l}2010 \\
1,880\end{array}$ & $\begin{array}{l}\text { Imputed gross monthly earnings. Missing } \\
\text { values have been replaced by the imputed net } \\
\text { monthly eamings (if available) converted in } \\
\text { gross earnings using the average \% difference } \\
\text { between the gross and net imputed earnings for } \\
\text { every } 500 \mathrm{CHF} \text { of net monthly earnings. }\end{array}$ & Monthly & Yes & & $\begin{array}{l}\text { Hours usually worked at } \\
\text { main job }\end{array}$ & & $\begin{array}{l}\text { Monthly eamings } \\
\text { divided by the usual } \\
\text { weekly hours worked } \\
\text { (multiplied by 52/12) }\end{array}$ \\
\hline $\begin{array}{l}\text { United } \\
\text { Kingdom }\end{array}$ & $\begin{array}{l}\text { British Household } \\
\text { Panel Survey } \\
\text { (BHPS) }\end{array}$ & $\begin{array}{l}\text { Persons aged } \\
15-54 \text { in the } \\
\text { reference year }\end{array}$ & $\begin{array}{r}2004-08 \\
37,266\end{array}$ & $\begin{array}{l}2008 \\
3,947\end{array}$ & $\begin{array}{l}\text { Gross annual earnings (excl. bonuses) and } \\
\text { bonuses received last year }\end{array}$ & Annual & Yes & Number of weeks worked & $\begin{array}{l}\text { Total usual hours worked in } \\
\text { main job (including overtime) }\end{array}$ & $\begin{array}{l}\text { Annual earnings } \\
\text { divided by the } \\
\text { number of months } \\
\text { worked }\end{array}$ & $\begin{array}{l}\text { Monthly eamings } \\
\text { divided by the usual } \\
\text { weekly hours worked } \\
\text { (multiplied by 52/12) }\end{array}$ \\
\hline United States & $\begin{array}{l}\text { Current Population } \\
\text { Survey (CPS) }\end{array}$ & $\begin{array}{l}\text { Persons aged } \\
15-54 \text { in the } \\
\text { reference year }\end{array}$ & $\begin{array}{r}2004-11 \\
87,222\end{array}$ & $\begin{array}{c}2010 \\
16,832\end{array}$ & $\begin{array}{l}\text { Average over } 12 \text { months of the total person's } \\
\text { earned income for the reference month }\end{array}$ & Monthly & Yes & & $\begin{array}{l}\text { Total usual hours worked in } \\
\text { all jobs }\end{array}$ & & $\begin{array}{l}\text { Monthly eamings } \\
\text { divided by the usual } \\
\text { weekly hours worked } \\
\text { (multiplied by 52/12) }\end{array}$ \\
\hline
\end{tabular}


Table A1. Detailed description of the data used (Cont.)

\begin{tabular}{|c|c|c|c|c|c|c|c|c|c|c|c|}
\hline \multirow[b]{2}{*}{ Country } & \multicolumn{2}{|c|}{ Survey description } & \multicolumn{2}{|c|}{ Estimations } & \multicolumn{3}{|c|}{ Annual earnings } & \multirow[b]{2}{*}{$\begin{array}{l}\text { Number of months } \\
\text { worked }\end{array}$} & \multirow[b]{2}{*}{ Hours worked } & \multirow[b]{2}{*}{$\begin{array}{l}\text { Monthly earnings } \\
\text { calculation }\end{array}$} & \multirow[b]{2}{*}{$\begin{array}{l}\text { Hourly earnings } \\
\text { calculation }\end{array}$} \\
\hline & Name & Sample & \begin{tabular}{|c|} 
Transitions \\
Period \& \\
Sample size \\
\end{tabular} & $\begin{array}{l}\text { Simulations } \\
\text { Ref. year \& } \\
\text { Sample size }\end{array}$ & Description & Freq. & $\begin{array}{c}\text { Wage } \\
\text { supplements } \\
\text { (bonus, tips, }\end{array}$ & & & & \\
\hline Austria & \multirow{17}{*}{$\begin{array}{l}\text { European Union } \\
\text { Statistics on Income } \\
\text { and Living } \\
\text { Conditions (EU- } \\
\text { SILC) }\end{array}$} & \multirow{17}{*}{$\begin{array}{l}\text { Persons aged } \\
15-54 \text { in the } \\
\text { reference } \\
\text { year (20-54 } \\
\text { for Denmark) }\end{array}$} & \begin{tabular}{|c|}
$2004-11$ \\
15,489 \\
\end{tabular} & \begin{tabular}{|l|}
2010 \\
1,809
\end{tabular} & \multirow{17}{*}{ Employee cash or near cash income } & \multirow{17}{*}{ Annual } & \multirow{17}{*}{ Yes } & \multirow{17}{*}{$\begin{array}{l}\text { Number of months worked } \\
\text { during the income reference } \\
\text { period (derived from the } \\
\text { calendar of activity). }\end{array}$} & \multirow{17}{*}{$\begin{array}{l}\text { Number of hours usually } \\
\text { worked per week in main } \\
\text { job during the month of } \\
\text { interview }\end{array}$} & \multirow{17}{*}{$\begin{array}{l}\text { Annual earnings } \\
\text { divided by the } \\
\text { number of months } \\
\text { worked during the } \\
\text { income reference } \\
\text { period. For Sweden } \\
\text { only annual earnings } \\
\text { are considered. }\end{array}$} & \multirow{17}{*}{$\begin{array}{l}\text { Monthly earnings } \\
\text { divided by the usual } \\
\text { weekly hours workec } \\
\text { (multiplied by 52/12). } \\
\text { For Sweden only } \\
\text { annual earnings are } \\
\text { considered. }\end{array}$} \\
\hline Belgium & & & $\begin{array}{r}2004-11 \\
14,517\end{array}$ & $\begin{array}{l}2010 \\
1,535\end{array}$ & & & & & & & \\
\hline Czech Rep & & & $\begin{array}{r}2004-11 \\
25,473\end{array}$ & $\begin{array}{l}2010 \\
1,653\end{array}$ & & & & & & & \\
\hline Denmark & & & $\begin{array}{c}2004-11 \\
8,067\end{array}$ & $\begin{array}{c}2010 \\
861\end{array}$ & & & & & & & \\
\hline Estonia & & & $\begin{array}{c}2004-11 \\
17,052\end{array}$ & $\begin{array}{l}2010 \\
1,827\end{array}$ & & & & & & & \\
\hline Finland & & & $\begin{array}{c}2004-11 \\
9,360\end{array}$ & $\begin{array}{r}2010 \\
974\end{array}$ & & & & & & & \\
\hline France & & & $\begin{array}{r}2004-11 \\
64,089\end{array}$ & $\begin{array}{l}2010 \\
9,065\end{array}$ & & & & & & & \\
\hline Greece & & & $\begin{array}{c}2004-11 \\
8,436\end{array}$ & $\begin{array}{l}2010 \\
1,462\end{array}$ & & & & & & & \\
\hline Italy & & & $\begin{array}{r}2004-11 \\
26,067\end{array}$ & $\begin{array}{r}2010 \\
4,085\end{array}$ & & & & & & & \\
\hline Netherlands & & & $\begin{array}{r}2004-11 \\
13,080\end{array}$ & $\begin{array}{l}2010 \\
1,750\end{array}$ & & & & & & & \\
\hline Poland & & & $\begin{array}{r}2004-11 \\
30,747\end{array}$ & $\begin{array}{l}2010 \\
3,735\end{array}$ & & & & & & & \\
\hline Portugal & & & $\begin{array}{c}2004-11 \\
9,246\end{array}$ & $\begin{array}{l}2010 \\
1,683\end{array}$ & & & & & & & \\
\hline Slovak Rep. & & & $\begin{array}{c}2004-10 \\
15,165\end{array}$ & $\begin{array}{l}2009 \\
2,718\end{array}$ & & & & & & & \\
\hline Slovenia & & & $\begin{array}{c}2004-11 \\
27,480\end{array}$ & $\begin{array}{l}2010 \\
3,927\end{array}$ & & & & & & & \\
\hline Spain & & & $\begin{array}{r}2004-11 \\
35,682\end{array}$ & $\begin{array}{l}2010 \\
4,333\end{array}$ & & & & & & & \\
\hline Sweden & & & $\begin{array}{c}2004-09 \\
13,578\end{array}$ & $\begin{array}{l}2008 \\
2,360\end{array}$ & & & & & & & \\
\hline Turkey & & & $\begin{array}{c}2004-11 \\
7,563\end{array}$ & $\begin{array}{l}2010 \\
1,376\end{array}$ & & & & & & & \\
\hline
\end{tabular}




\section{AI.2 External data validation}

An external validation is conducted to assess how well the data used in this paper can reproduce cross-country patterns based on standardised indicators on inequality and unemployment as produced by the OECD. Estimates of unemployment based on the household panel surveys used in this paper are compared with the OECD Labour Force Statistics Database using data for the reference year of the simulations. Estimates of inequality from household surveys are compared with those published in the OECD Earnings Database for the reference year. To allow making appropriate comparisons, the same concepts of unemployment and earnings are used as in the OECD Earnings Database.

The results from the validation analysis are summarised in Table A2 by means of three statistics: i) the R-squared of a regression of the country-level values in the standardised databases produced by the OECD on their corresponding values in the data used in this paper (without a constant) to measure the goodness of fit; ii) the slope coefficient of the same regression to highlight any systematic differences between the sources; and iii) the p-value of a two-sided t-test that assesses whether the slope coefficient is equal to one.

The results from the external validation exercise suggest that the data used in this paper can reproduce the OECD measures of unemployment and inequality rather well. Country-level unemployment rates in the household data capture about $93 \%$ of the cross-country variation in unemployment rates in the standardised OECD data. The household data have a tendency to overestimate the incidence of unemployment. The household data do even better in terms of inequality, explaining around $99 \%$ of the variation in inequality across countries. While the slope coefficient 
is typically very close to one there is some indication that the household data underestimate the degree of inequality.

Table A2. External data validation: household data used in this paper versus standardised OECD data 2010

\begin{tabular}{c|ccc}
\hline & $\mathrm{R}^{2}$ & Coefficient & P-value \\
\hline $\begin{array}{c}\text { Incidence of unemployment } \\
\text { Earnings inequality of full- } \\
\text { time wage and salary workers: }\end{array}$ & 0.927 & 0.883 & 0.028 \\
P90/P10 & & & \\
P80/P20 & 0.983 & 1.066 & 0.037 \\
P90/P50 & 0.990 & 1.039 & 0.113 \\
P50/P10 & 0.990 & 1.083 & 0.003 \\
\hline
\end{tabular}

Note: The R-squared and the slope coefficient are obtained from a regression of the country-level values in the standardised databases produced by the OECD on their corresponding values in the data used in this paper (without a constant). The p-value relates to a two-sided t-test of the hypothesis that the slope coefficient is equal to one.

Source: The standardised OECD databases correspond to OECD Labour Force Statistics Database and OECD Earnings Database. The data used for the analysis in this paper are: European Union Statistics on Income and Living Conditions (EU-SILC) for European countries and Turkey; Household, Income and Labour Dynamics (HILDA) for Australia; British Household Panel Survey (BHPS) for the United Kingdom; German Socio-Economic Panel (GSOEP) for Germany; Keio Household Panel Survey (KHPS) for Japan; Korean Labor and Income Panel Study (KLIPS) for Korea; Swiss Household Panel (SHP) for Switzerland and Survey of Income and Program Participation (SIPP) for the United States.

\section{AI.3 Internal data validation}

The next step is to assess the internal validity of the simulated data for inequality and unemployment in 2011 with those in the same year in the actual data. Table A3 summarises the results using the same three statistics as in the case of the external validation above based on a regression (without constant) of the country-level values in the actual data on their corresponding values in the simulations data in the same year.

The simulated data reproduce well the real unemployment rate of each country: the simulated data captures $94 \%$ of the cross-country variation in unemployment rates in the actual data, and the slope coefficient is not significantly different from one. Overall, the estimates of inequality in the 
simulated data using show a very good fit of the cross-country variation in the actual data. The Rsquared typically exceeds 0.87 and the slope coefficient are not significantly different from one.

The simulated degree of benefit coverage is very similar to that observed in the actual data. The variation in coverage rates in the simulated data is not only very similar to that observed in the actual data the average level is also similar. The generosity of benefits is not validated since this is computed using the OECD taxes and benefits model and hence unaffected by the statistical simulation approach used in this paper.

Table A3. Internal data validation: actual versus simulated data

\begin{tabular}{l|ccc}
\multicolumn{4}{|c}{2011} \\
\hline \\
\hline Incidence of unemployment & $\mathrm{R}^{2}$ & Coefficient & P-value \\
\hline Earnings inequality of actives & 0.947 & 1.036 & 0.605 \\
$\quad$ & & & \\
Gini coefficient & 0.996 & 1.007 & 0.601 \\
Theil index* & 0.980 & 1.012 & 0.715 \\
Mean Logarithmic Deviation (MLD) & 0.965 & 1.058 & 0.172 \\
P90/P10 & 0.725 & 1.113 & 0.272 \\
P80/P20 & 0.681 & 1.290 & 0.179 \\
P90/P50 & 0.997 & 0.972 & 0.022 \\
P50/P10 & 0.736 & 1.150 & 0.141 \\
Unemployment benefit coverage & 0.957 & 0.949 & 0.178 \\
\hline
\end{tabular}

*: For the calculations of the Theil index and MLD, income of unemployed who did not received any unemployment benefits are replaced by $10 \%$ of the median earnings.

Note: The R-squared and the slope coefficient are obtained from a regression of the country-level values in the actual data on their corresponding values in the simulated data (without a constant). The $\mathrm{p}$-value relates to a two-sided t-test of the hypothesis that the slope coefficient is equal to one.

Source: OECD calculations based on the European Union Statistics on Income and Living Conditions (EU-SILC) for European countries and Turkey; Household, Income and Labour Dynamics (HILDA) for Australia; British Household Panel Survey (BHPS) for the United Kingdom; German Socio-Economic Panel (GSOEP) for Germany; Keio Household Panel Survey (KHPS) for Japan; Korean Labor and Income Panel Study (KLIPS) for Korea; Swiss Household Panel (SHP) for Switzerland and Survey of Income and Program Participation (SIPP) for the United States. 


\section{ANNEX II: DISTRIBUTION OF REAL AND SIMULATED EARNINGS IN ITALY}

Figure A1 compares the actual distribution of earnings in the Italian Social Security data over the period 2003-2012 with that in the simulated data for each of the three specifications (OLS = ordinary least squares, FE = fixed effects, DYN = dynamic). Since the estimation period for the simulation parameters corresponds to the period 2001-2003, this effectively involves comparing the out-of-sample predictions with the actual data. The figure shows that the mode in the actual data is slightly higher than that in the simulated data.

Apart from showing the resulting distributions, Table A4 also compares the first four moments of earnings of the actual and the simulated distributions. ${ }^{32}$ It shows that each of the three simulation procedures captures the mean and the standard deviation rather well. Differences are more pronounced in the case of the skewness and kurtosis measures. ${ }^{33}$ While the simulations based on fixed effects capture skewness and kurtosis rather well, those based on the OLS and dynamic specifications tend to overestimate the degree of asymmetry and the fatness of the tails. While capturing these higher moments well is important for documenting inequality, it may be less of an issue for the purposes of describing positional mobility.

\footnotetext{
32 Mean measures the average, standard deviation measures dispersion, skewness measures asymmetry and kurtosis the weight of the tails. 
Figure A1 Distribution of real and simulated earnings in Italy

Earnings distribution in real and simulated data, 2003-12

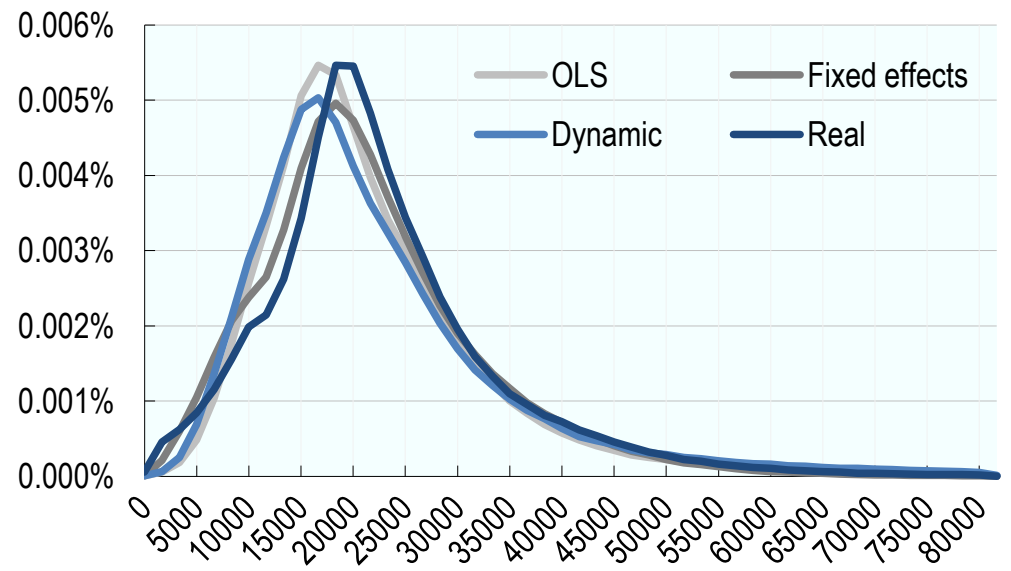

Source: Authors' estimates based on INPS data.

Table A4. Actual and predicted moments in the actual and simulated data

2003-12

\begin{tabular}{l|c|c|c|c}
\hline & Actual & OLS Simulation & $\begin{array}{c}\text { Fix ed effects } \\
\text { simulation }\end{array}$ & $\begin{array}{c}\text { Dy namic } \\
\text { simulation }\end{array}$ \\
\hline Mean & 22,215 & 21,835 & 21,165 & 22,482 \\
Standard deviation & 11,327 & 12,724 & 10,672 & 14,670 \\
Skewness & 1.38 & 2.64 & 1.14 & 2.60 \\
Kurtosis & 6.81 & 15.70 & 5.56 & 14.69 \\
\hline
\end{tabular}

Source: Authors' estimates based on INPS data. 
ANNEX III: FURTHER RESULTS

Table A5. Short-term inequality, long-term inequality and mobility across countries

Based on simulations over ten or twenty years, employed onlya

\begin{tabular}{|c|c|c|c|c|c|c|c|c|c|c|c|c|c|c|c|c|c|c|c|c|c|c|c|c|}
\hline \multirow[b]{4}{*}{ Average } & \multicolumn{6}{|c|}{ Gini coefficient } & \multirow{2}{*}{\multicolumn{3}{|c|}{$\begin{array}{l}\text { Theil index } \\
\text { over } 10 \text { years }\end{array}$}} & \multirow{2}{*}{\multicolumn{3}{|c|}{$\begin{array}{c}\text { Mean Logarithmic Deviation } \\
\text { (MLD) } \\
\text { over } 10 \text { years }\end{array}$}} & \multirow{2}{*}{\multicolumn{3}{|c|}{$\begin{array}{l}\text { Ratio P80/P20 } \\
\text { over } 10 \text { years }\end{array}$}} & \multirow{2}{*}{\multicolumn{3}{|c|}{$\begin{array}{l}\text { Ratio P90/P10 } \\
\text { over } 10 \text { years }\end{array}$}} & \multirow{2}{*}{\multicolumn{3}{|c|}{$\begin{array}{l}\text { Ratio P90/P50 } \\
\text { over } 10 \text { years }\end{array}$}} & \multirow{2}{*}{\multicolumn{3}{|c|}{$\begin{array}{l}\text { Ratio P50/P10 } \\
\text { over } 10 \text { years }\end{array}$}} \\
\hline & \multicolumn{3}{|c|}{ Over 20 years } & \multicolumn{3}{|c|}{ Over 10 years } & & & & & & & & & & & & & & & & & & \\
\hline & Short-ter & ong-term & Mobility & Short-tert & Long-tern & Mobility & Short-ter & ong-term & Mobility & Short-ter & Long-term & Mobility & Short-ter & ong-term & Mobility & Short-ter & -ong-term & Mobility & Short-ter & Long-term & Mobility & Short-ter & Long-term & Mobility \\
\hline & 0.22 & 0.18 & 16.9 & 0.28 & 0.25 & 7.6 & \begin{tabular}{|l|} 
\\
0.13
\end{tabular} & 0.11 & 15.9 & \begin{tabular}{|l|}
0.13 \\
\end{tabular} & 0.11 & 16.1 & 2.38 & 2.26 & 5.3 & 3.84 & 3.50 & 8.7 & 1.91 & 1.84 & 3.5 & 1.98 & 1.87 & 5.4 \\
\hline Austria & 0.24 & 0.20 & 17.1 & 0.29 & 0.26 & 9.9 & 0.14 & 0.11 & 20.6 & 0.14 & 0.11 & 20.2 & 2.47 & 2.29 & 7.4 & 4.09 & 3.68 & 10.0 & 1.94 & 1.83 & 5.6 & 2.10 & 2.01 & 4.6 \\
\hline Belgium & 0.16 & 0.12 & 23.1 & 0.24 & 0.22 & 7.6 & 0.09 & 0.08 & 15.4 & 0.09 & 0.08 & 15.8 & 1.98 & 1.87 & 5.2 & 2.94 & 2.70 & 8.0 & 1.74 & 1.67 & 3.7 & 1.69 & 1.62 & 4.4 \\
\hline Czech Republic & 0.19 & 0.16 & 16.1 & 0.22 & 0.20 & 9.3 & 0.08 & 0.07 & 18.5 & 0.08 & 0.07 & 19.0 & 1.91 & 1.81 & 5.5 & 2.75 & 2.54 & 7.5 & 1.63 & 1.55 & 4.4 & 1.69 & 1.64 & 3.2 \\
\hline Denmark & 0.17 & 0.15 & 8.9 & 0.17 & 0.16 & 7.3 & 0.05 & 0.04 & 14.8 & 0.05 & 0.04 & 15.6 & 1.65 & 1.60 & 2.9 & 2.17 & 2.08 & 4.1 & 1.49 & 1.48 & 0.6 & 1.45 & 1.40 & 3.6 \\
\hline Estonia & 0.30 & 0.26 & 12.8 & 0.32 & 0.29 & 8.9 & 0.17 & 0.14 & 18.9 & 0.17 & 0.14 & 18.8 & 2.61 & 2.42 & 7.2 & 4.42 & 3.80 & 14.0 & 2.19 & 2.07 & 5.6 & 2.02 & 1.84 & 8.9 \\
\hline France & 0.23 & 0.20 & 11.2 & 0.27 & 0.26 & 5.1 & 0.13 & 0.11 & 10.9 & 0.13 & 0.11 & 11.7 & 2.15 & 2.08 & 3.3 & 3.42 & 3.18 & 7.1 & 1.89 & 1.85 & 2.3 & 1.81 & 1.72 & 4.9 \\
\hline Germany & 0.26 & 0.21 & 16.7 & 0.32 & 0.30 & 4.9 & 0.17 & 0.15 & 11.0 & 0.17 & 0.16 & 10.0 & 2.63 & 2.51 & 4.5 & 4.53 & 4.27 & 5.7 & 2.04 & 1.98 & 3.1 & 2.22 & 2.16 & 2.8 \\
\hline Greece & 0.18 & 0.13 & 25.2 & 0.22 & 0.19 & 12.4 & 0.08 & 0.06 & 23.3 & 0.08 & 0.06 & 23.6 & 1.86 & 1.70 & 8.8 & 2.67 & 2.30 & 13.8 & 1.59 & 1.48 & 7.0 & 1.67 & 1.55 & 7.3 \\
\hline Italy & 0.18 & 0.16 & 15.9 & 0.25 & 0.23 & 6.2 & 0.10 & 0.09 & 13.2 & 0.10 & 0.09 & 13.5 & 2.06 & 1.97 & 4.2 & 3.09 & 2.89 & 6.4 & 1.76 & 1.72 & 2.3 & 1.76 & 1.69 & 4.2 \\
\hline Japan & 0.29 & 0.27 & 9.2 & 0.38 & 0.37 & 4.8 & 0.24 & 0.22 & 10.2 & 0.29 & 0.26 & 9.6 & 4.61 & 4.37 & 5.4 & 8.79 & 8.22 & 6.5 & 2.14 & 2.09 & 2.4 & 4.12 & 3.94 & 4.4 \\
\hline Korea & 0.24 & 0.19 & 21.4 & 0.30 & 0.28 & 7.5 & 0.15 & 0.12 & 16.2 & 0.15 & 0.13 & 15.4 & 2.68 & 2.50 & 6.6 & 4.47 & 4.03 & 9.9 & 2.02 & 1.89 & 6.5 & 2.21 & 2.13 & 3.6 \\
\hline Netherlands & 0.10 & 0.08 & 18.5 & 0.25 & 0.24 & 4.0 & 0.10 & 0.09 & 9.3 & 0.10 & 0.09 & 8.9 & 2.11 & 2.04 & 2.9 & 3.15 & 3.08 & 2.4 & 1.71 & 1.70 & 0.3 & 1.85 & 1.81 & 2.1 \\
\hline Poland & 0.24 & 0.20 & 19.2 & 0.28 & 0.25 & 10.4 & 0.12 & 0.10 & 22.0 & 0.12 & 0.10 & 21.8 & 2.31 & 2.19 & 5.3 & 3.54 & 3.14 & 11.4 & 1.96 & 1.87 & 4.6 & 1.81 & 1.68 & 7.1 \\
\hline Portugal & 0.24 & 0.22 & 9.0 & 0.33 & 0.31 & 4.9 & 0.18 & 0.16 & 10.1 & 0.17 & 0.15 & 10.7 & 2.64 & 2.59 & 1.6 & 4.36 & 3.93 & 9.7 & 2.56 & 2.45 & 4.4 & 1.70 & 1.61 & 5.7 \\
\hline Slovak Republic & 0.17 & 0.13 & 24.4 & 0.20 & 0.18 & 12.2 & 0.07 & 0.05 & 23.8 & 0.07 & 0.05 & 24.0 & 1.82 & 1.67 & 8.4 & 2.49 & 2.25 & 9.7 & 1.58 & 1.52 & 3.5 & 1.58 & 1.48 & 6.4 \\
\hline Sweden ${ }^{b}$ & 0.22 & 0.16 & 25.7 & 0.25 & 0.23 & 8.7 & 0.11 & 0.09 & 18.6 & 0.11 & 0.09 & 20.5 & 2.01 & 1.92 & 4.6 & 3.14 & 2.77 & 11.5 & 1.82 & 1.80 & 1.1 & 1.72 & 1.54 & 10.5 \\
\hline Switzerland & 0.17 & 0.14 & 15.7 & 0.24 & 0.23 & 7.5 & 0.10 & 0.08 & 14.8 & 0.11 & 0.10 & 14.9 & 2.13 & 2.04 & 4.1 & 3.62 & 3.34 & 7.7 & 1.60 & 1.54 & 3.9 & 2.26 & 2.17 & 3.9 \\
\hline Turkey & 0.22 & 0.18 & 19.5 & 0.29 & 0.27 & 8.1 & 0.14 & 0.11 & 17.1 & 0.14 & 0.11 & 17.2 & 2.51 & 2.32 & 7.7 & 3.77 & 3.30 & 12.3 & 2.04 & 1.95 & 4.6 & 1.85 & 1.70 & 8.1 \\
\hline United Kingdom & 0.27 & 0.23 & 16.0 & 0.32 & 0.30 & 6.8 & 0.17 & 0.15 & 14.6 & 0.18 & 0.15 & 14.2 & 2.71 & 2.48 & 8.4 & 4.72 & 4.27 & 9.4 & 2.09 & 2.02 & 3.0 & 2.26 & 2.11 & 6.5 \\
\hline United States & 0.34 & 0.29 & 13.3 & 0.39 & 0.37 & 6.9 & 0.27 & 0.22 & 16.5 & 0.26 & 0.22 & 15.7 & 3.36 & 3.17 & 5.5 & 6.28 & 5.70 & 9.2 & 2.61 & 2.54 & 2.5 & 2.41 & 2.24 & 6.8 \\
\hline $\begin{array}{l}\text { Correlation short- } \\
\text { term inequality- }\end{array}$ & & -0.34 & & & $-0.38^{*}$ & & & -0.29 & & & $-0.38^{*}$ & & & 0.11 & & & 0.04 & & & 0.12 & & & -0.07 & \\
\hline
\end{tabular}

. : statistically significant at $1 \%, 5 \%$ and $10 \%$ levels, respectively.

a) Simulations are based on individuals aged 15 to 54 in the reference year and aged 15-24 for active persons over 20 years (aged 20-54 and 20-29 for Denmark and Japan).

b) Results based on annual earnings.

Source: Authors' calculations based on the European Union Statistics on Income and Living Conditions (EU-SILC) for European countries and Turkey, Household, Income and Labour Dynamics (HILDA) for Australia, German SOcio-Economic Panel (GSOEP) for Germany, Keio Household Panel Survey (KHPS) for Japan, Korean Labor and Income Panel Study (KLIPS) for Korea, Swiss Household Panel (SHP) for Switzerland and Survey of Income and Program Participation (SIPP) for the United States. 
Table A.6. Correlations between short-term inequality and earnings mobility across the distribution, by groups

Employed persons

\begin{tabular}{|c|c|c|c|c|c|c|c|c|c|c|c|c|c|c|c|c|c|}
\hline $\begin{array}{c}\text { Percentile } \\
\text { ratio }\end{array}$ & Total & & Men & & Wom & & Yout| & & Prime $A$ & Ige & $\begin{array}{l}\text { Olde } \\
\text { worke }\end{array}$ & & $\begin{array}{l}\text { Low- } \\
\text { skilled }\end{array}$ & & $\begin{array}{r}\text { Medium } \\
\text { skilled }\end{array}$ & & $\begin{array}{l}\text { High- } \\
\text { skilled }\end{array}$ \\
\hline P20/P10 & -0.35 & * & 0.19 & & 0.12 & & 0.17 & & -0.19 & & 0.14 & & -0.26 & & -0.11 & & -0.02 \\
\hline P30/P20 & -0.09 & & 0.41 & $* *$ & 0.19 & & 0.08 & & -0.41 & $* *$ & -0.04 & & -0.05 & & -0.22 & & 0.30 \\
\hline P40/P30 & 0.04 & & 0.06 & & -0.19 & & 0.53 & $* * *$ & -0.07 & & -0.22 & & -0.22 & & -0.37 & * & 0.09 \\
\hline P50/P40 & 0.33 & & 0.54 & $* * *$ & 0.53 & $* * *$ & -0.17 & & 0.26 & & 0.46 & $* *$ & 0.08 & & -0.20 & & 0.32 \\
\hline P60/P50 & -0.01 & & -0.11 & & 0.22 & & -0.15 & & 0.21 & & -0.26 & & -0.16 & & 0.39 & * & -0.17 \\
\hline P70/P60 & 0.02 & & 0.12 & & -0.59 & $* * *$ & 0.24 & & 0.01 & & 0.04 & & 0.08 & & 0.18 & & 0.15 \\
\hline P80/P70 & 0.02 & & -0.06 & & 0.16 & & 0.09 & & 0.25 & & -0.22 & & 0.32 & & -0.12 & & -0.11 \\
\hline P90/P80 & 0.31 & & 0.45 & ** & 0.35 & * & -0.02 & & 0.17 & & 0.40 & * & 0.37 & * & 0.17 & & 0.22 \\
\hline
\end{tabular}

${ }^{* * *},{ }^{* *}, *$ : statistically significant at $1 \%, 5 \%$ and $10 \%$ levels, respectively.

Source: Authors' calculations based on the European Union Statistics on Income and Living Conditions (EU-SILC) for European Union countries and Turkey, Household, Income and Labour Dynamics (HILDA) for Australia, British Household Panel (BHPS) for the United Kingdom, German SOcio-Economic Panel (GSOEP) for Germany, Keio Household Panel Survey (KHPS) for Japan, Korean Labor and Income Panel Study (KLIPS) for Korea, Swiss Household Panel (SHP) for Switzerland and Survey of Income and Program Participation (SIPP) for the United States.

Figure A2. Inequality, mobility and the correlation between inequality and mobility across the distribution

A. Earnings inequality (percentile ratios for each decile)

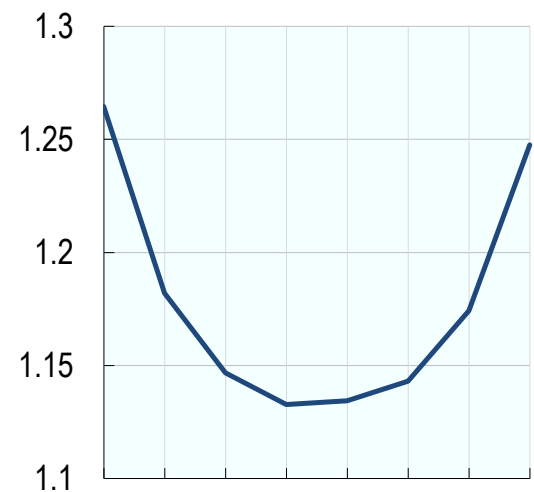

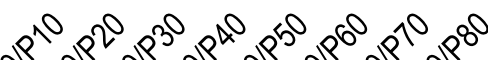

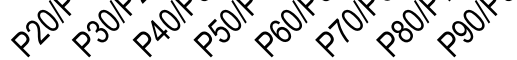

Employed only

B. Earnings mobility

(Shorrocks index for each decile)

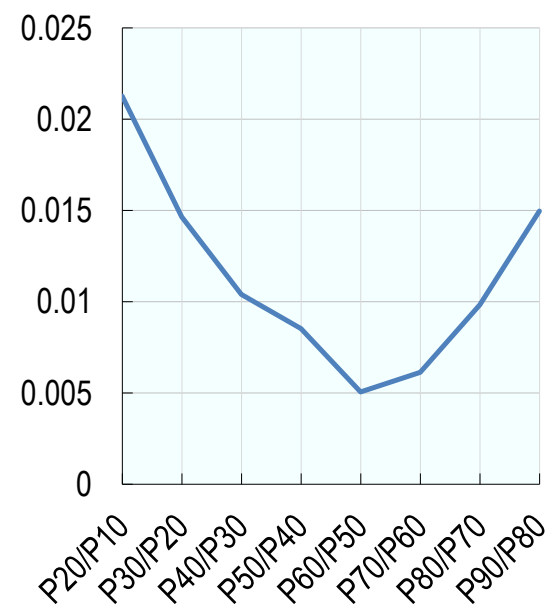

C. Correlation mobility-inequality in each decile

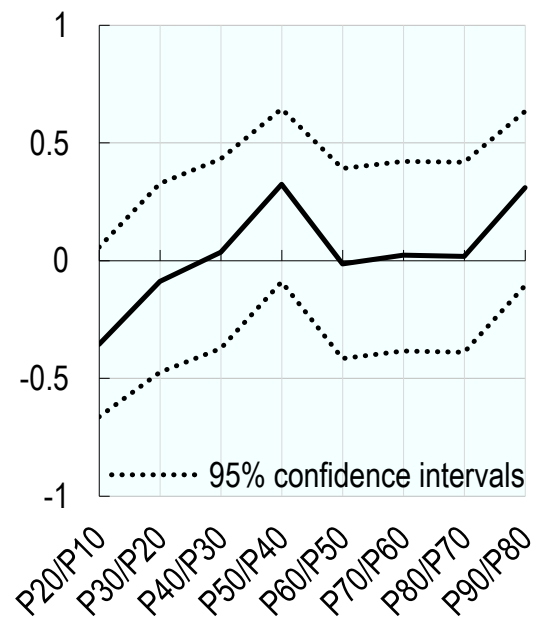

Source: Authors' calculations based on the European Union Statistics on Income and Living Conditions (EU-SILC) for European Union countries and Turkey, Household, Income and Labour Dynamics (HILDA) for Australia, British Household Panel (BHPS) for the United Kingdom, German Socio-Economic Panel (GSOEP) for Germany, Keio Household Panel Survey (KHPS) for Japan, Korean Labor and Income Panel Study (KLIPS) for Korea, Swiss Household Panel (SHP) for Switzerland and Survey of Income and Program Participation (SIPP) for the United States. 


\section{ANNEX IV: SENSITIVITY ANALYSIS}

Table A7 provides a detailed assessment of the sensitivity of the baseline results to changes in the simulation procedure. Baseline results are compared to those that are obtained by changing one feature of the simulation procedure at a time. The sensitivity analysis focuses on the countrylevel estimates of short-term earnings inequality, long-term earnings inequality, earnings mobility and the correlation between short-term inequality and mobility. Each outcome is measured in terms of the Gini coefficient and the P90/P10 ratio over ten years. The results from the sensitivity analysis are summarised by means of three statistics i) the R-squared of a regression of the country-level estimates obtained in the baseline procedure with the corresponding estimates using the alternative procedure (without a constant); ii) the slope coefficient of the same regression; and iii) the p-value of a two-sided t-test that assesses whether the slope coefficient is equal to one.

- Coefficient restrictions on large earnings transitions. Panel A compares the baseline results that were obtained by restricting the estimated probabilities of making transitions of three or more earnings deciles to be the same with results that respectively allow for more flexibility, by allowing explicitly for transitions between four deciles, or less flexibility, by restricting transitions between two or more earnings deciles to be the same. The price of flexibility in the present context is that the multinomial estimates of employment and earnings dynamics fail to achieve convergence for some countries where the sample size is relatively smaller while more restrictive specifications yield convergence in the large majority of cases. The results indicate that coefficient restrictions have only small effects on estimates of short-term and long-term earnings inequality and hence mobility. For both 
the Gini index and the P90/P10 ratio the regression coefficients are not significantly different from one.

- Monthly earnings versus hourly wages. Panel B compares results based on monthly earnings and hourly wages. They indicate that using hourly wages instead yields lower estimates of short-term earnings inequality, long-term inequality and earnings mobility. This reflects the fact that differences in working time amplify earnings inequalities. The underestimation of mobility implies that mobility is not only driven by changes in hourly wages and changes in and out of employment but also by changes in working time.

- The choice of the reference year. Panel $\mathrm{C}$ compares the baseline results obtained with using 2010 as the reference year with those using the earliest available year, i.e. 2006, and those using the latest available year, i.e. 2011. The reference year determines the initial values that are used for the simulations but does not affect the estimation of the simulation parameters. The results indicate that the choice of the reference year does not affect the results: the slope coefficient is not statistically different from one in any of the specifications.

- Discounting future earnings. Panel D compares the baseline results which do not discount the future with results that adopt a discount rate of 2.5 and $5 \%$ respectively. Using strictly positive discount rates does not affect the estimates.

- Imposing a minimum income floor. Panel E compares the baseline results with those that are obtained imposing a minimum income for unemployed persons of respectively 5 and $10 \%$ of the median. This test is motivated by both conceptual and technical arguments. First, the present analysis does take not account of social assistance as a source of income 
support to unemployed persons even though this tends to be important in many OECD countries. Second, not all inequality indices can be calculated in the presence of zero earnings (e.g. Theil index, the MLD, percentile ratios), and, if they can, they tend to be very sensitive to small values in some cases. While imposing a minimum income floor is arbitrary, it does help to address these issues, at least to some extent. The results show that, in line with expectations, imposing a minimum income floor slightly reduces short-term inequality, long-term inequality as well as mobility when using the Gini. By contrast, imposing income floor of $5 \%$ of the median instead of $10 \%$ for the P90/P10 ratio compared slightly increases mobility. However, since the R-Squared is essentially equal to one, this choice does not affect country rankings to a significant extent.

Finally the correlation between short-term earnings inequality and mobility does not depend on the specific way the simulation procedure was implemented. The correlation coefficient between inequality and mobility with the Gini index is statistically insignificant in all cases. The correlation coefficient with the P90/P10 ratio is positive and statistically significant in all cases except when hourly earnings are used. 
Table A7. Sensitivity analysis

Active persons (ten years)

\begin{tabular}{|c|c|c|c|c|c|c|c|c|c|c|c|c|c|c|}
\hline & & \multicolumn{5}{|c|}{$\begin{array}{l}\text { A. Coefficient restrictions on large earnings } \\
\text { transitions: }\end{array}$} & \multirow{2}{*}{\multicolumn{3}{|c|}{\begin{tabular}{|c|}
$\begin{array}{c}\text { B. Earnings concept: } \\
\text { Monthly earnings versus: }\end{array}$ \\
Hourly earnings
\end{tabular}}} & \multicolumn{5}{|c|}{ C. Reference year: 2010 versus: } \\
\hline & & \multicolumn{3}{|c|}{ Less flex ibility ( $k=2$ ) } & \multicolumn{2}{|c|}{ More flex ibility $(k=4)$} & & & & \multicolumn{3}{|c|}{2006} & \multicolumn{2}{|c|}{2011} \\
\hline & & $\begin{array}{c}\text { Gini } \\
\text { coefficient }\end{array}$ & $\begin{array}{r}\text { Ratio } \\
\text { P9o/P }\end{array}$ & & $\begin{array}{l}\text { Gini } \\
\text { coefficient }\end{array}$ & $\begin{array}{l}\text { Ratio } \\
\text { P90/P10 }\end{array}$ & $\begin{array}{l}\text { Gini } \\
\text { coefficient }\end{array}$ & $\begin{array}{c}\text { Ratio } \\
\text { P90/P10 }\end{array}$ & & Gini coefficient & $\begin{array}{r}\text { Ratio } \\
\text { P90/P1 }\end{array}$ & & $\begin{array}{c}\text { Gini } \\
\text { coefficient }\end{array}$ & $\begin{array}{c}\text { Ratio } \\
\text { P90/P10 }\end{array}$ \\
\hline \multicolumn{2}{|c|}{ Short-term inequality $\mathrm{R}^{2}$} & 0.999 & 0.965 & & 0.999 & 0.977 & 0.984 & 0.684 & & 0.998 & 0.968 & & 0.999 & 0.995 \\
\hline & Coeff. & 0.995 & 0.925 & & 0.991 & 0.935 & 1.296 & 2.395 & & 1.005 & 0.998 & & 1.004 & 0.983 \\
\hline & $P$-value & 0.508 & 0.191 & & 0.074 & 0.131 & 0.000 & 0.001 & & 0.618 & 0.977 & & 0.574 & 0.164 \\
\hline \multicolumn{2}{|c|}{ Long-term inequality $\mathrm{R}^{2}$} & 0.999 & 0.996 & & 1.000 & 0.997 & 0.984 & 0.932 & & 0.998 & 0.978 & & 0.999 & 0.993 \\
\hline & Coeff. & 1.003 & 1.002 & & 0.990 & 0.962 & 1.269 & 1.494 & & 1.003 & 0.968 & & 1.002 & 0.964 \\
\hline & $P$-value & 0.589 & 0.919 & & 0.032 & 0.022 & 0.000 & 0.000 & & 0.734 & 0.525 & & 0.817 & 0.093 \\
\hline \multirow[t]{3}{*}{ Earnings mobility } & $\mathrm{R}^{2}$ & 0.986 & 0.941 & & 0.993 & 0.953 & 0.967 & 0.655 & & 0.995 & 0.942 & & 0.996 & 0.968 \\
\hline & Coeff. & 0.927 & 0.906 & & 0.996 & 0.960 & 1.155 & 3.136 & & 1.000 & 0.910 & & 1.010 & 0.986 \\
\hline & $P$-value & 0.005 & 0.186 & & 0.832 & 0.502 & 0.003 & 0.000 & & 0.998 & 0.153 & & 0.428 & 0.742 \\
\hline \multirow{4}{*}{\multicolumn{2}{|c|}{$\begin{array}{l}\text { Correlation coefficient } \\
\text { short-term inequality- } \\
\text { earnings mobility }\end{array}$}} & 0.177 & 0.950 & $* * *$ & 0.177 & $0.953^{* * *}$ & -0.194 & 0.553 & & 0.198 & 0.865 & $* * *$ & 0.171 & $0.905 * * * *$ \\
\hline & & \multicolumn{5}{|c|}{ D. Discount rates: no discount rate versus: } & \multicolumn{6}{|c|}{$\begin{array}{l}\text { E. Imposing minimum income floor for } \\
\text { unemployed: }\end{array}$} & & \\
\hline & & \multicolumn{3}{|c|}{$2.5 \%$} & \multicolumn{2}{|c|}{$5.0 \%$} & \multicolumn{3}{|c|}{$5 \%$ of median earnings } & \multicolumn{2}{|c|}{$10 \%$ of median earnings } & & & \\
\hline & & $\begin{array}{l}\text { Gini } \\
\text { coefficient }\end{array}$ & $\begin{array}{l}\text { Ratio } \\
\text { P90/P }\end{array}$ & & $\begin{array}{l}\text { Gini } \\
\text { coefficient }\end{array}$ & $\begin{array}{l}\text { Ratio } \\
\text { P90/P10 }\end{array}$ & Gini coefficient & $\begin{array}{c}\text { Ratio } \\
\text { P90/P10 }\end{array}$ & & Gini coefficient & & & & \\
\hline \multicolumn{2}{|c|}{ Short-term inequality $\mathrm{R}^{2}$} & 1.000 & 1.000 & & 1.000 & 1.000 & 1.000 & 0.930 & & 1.000 & & & & \\
\hline & Coeff. & 1.000 & 1.000 & & 1.000 & 1.000 & 1.010 & 0.565 & & 1.021 & & & & \\
\hline & $P$-value & 0.902 & 0.720 & & 0.902 & 0.720 & 0.000 & 0.000 & & 0.000 & & & & \\
\hline \multicolumn{2}{|c|}{ Long-term inequality $\mathrm{R}^{2}$} & 1.000 & 1.000 & & 1.000 & 1.000 & 1.000 & 0.997 & & 1.000 & & & & \\
\hline & Coeff. & 0.999 & 0.998 & & 1.000 & 0.998 & 1.009 & 0.957 & & 1.019 & & & & \\
\hline & $P$-value & 0.530 & 0.262 & & 0.844 & 0.262 & 0.000 & 0.013 & & 0.000 & & & & \\
\hline \multirow[t]{3}{*}{ Earnings mobility } & $\mathrm{R}^{2}$ & 0.998 & 1.000 & & 0.997 & 1.000 & 1.000 & 0.989 & & 1.000 & & & & \\
\hline & Coeff. & 1.009 & 1.003 & & 1.007 & 1.003 & 1.007 & 0.885 & & 1.014 & & & & \\
\hline & $P$-value & 0.341 & 0.180 & & 0.535 & 0.180 & 0.000 & 0.000 & & 0.000 & & & & \\
\hline \multicolumn{2}{|c|}{$\begin{array}{l}\text { short-term inequality- } \\
\text { earnings mobility }\end{array}$} & 0.256 & 0.950 & $* * *$ & 0.270 & 0.950 & 0.178 & 0.949 & $* * *$ & 0.153 & & & & \\
\hline
\end{tabular}

${ }^{* * *},{ }^{* *},{ }^{*}$ : statistically significant at $1 \%, 5 \%$ and $10 \%$ levels, respectively.

Source: Authors' calculations based on the European Union Statistics on Income and Living Conditions (EU-SILC) for European Union countries and Turkey, Household, Income and Labour Dynamics (HILDA) for Australia, British Household Panel (BHPS) for the United Kingdom, German Socio-Economic Panel (GSOEP) for Germany, Keio Household Panel Survey (KHPS) for Japan, Korean Labor and Income Panel Study (KLIPS) for Korea, Swiss Household Panel (SHP) for Switzerland and Survey of Income and Program Participation (SIPP) for the United States. 